\title{
ipen
}

AUTARQUIA ASSOCIADA À UNIVERSIDADE DE SÃO PAULO

\section{ESTUDO DO EFEITO DA RADIAÇÃO IONIZANTE NA UTILIZAÇÃO DOS CATALISADORES DESATIVADOS DE CRAQUEAM ENTO}

Fernando Mantovani Kondo

Dissertação apresentada como parte dos requisitos para obtenção do Grau de Mestre em Ciências na Área de Tecnologia Nuclear - Aplicações

Orientador:

Prof. Dr. Wilson Aparecido Parejo Calvo 


\title{
INSTITUTO DE PESQUISAS ENERGÉTICAS E NUCLEARES
}

Autarquia associada à Universidade de São Paulo

\section{ESTUDO DO EFEITO DA RADIAÇÃO IONIZANTE NA UTILIZAÇÃO DOS CATALISADORES DESATIVADOS DE CRAQUEAM ENTO}

\author{
Fernando Mantovani Kondo
}

Dissertação apresentada como parte dos requisitos para obtenção do Grau de Mestre em Ciências na Área de Tecnologia Nuclear - Aplicações

Orientador:

Prof. Dr. Wilson Aparecido Parejo Calvo

Versão Corrigida

Versão Original disponível no IPEN

São Paulo

2014 
Àtranfomax̧ãa 


\section{AGRADECIMENTOS}

Ao meu orientador Dr. Wilson Aparecido Parejo Calvo pela sua paciência, orientação e perspicácia. Colaborando sempre com argumentos positivos, impulsionando-me, em todas as discussões, com energia revigorante.

Ao Centro de Tecnologia das Radiações que me acolheu e cedeu-me suas instalações, representado pela Dra. Margarida Mizue Hamada, gerente do CTR, gerentes adjuntos Dra. Mônica Beatriz Mathor e Dr. Wilson Aparecido Parejo Calvo.

Ao Dr. Nelson Batista de Lima, pelas valorosas análises, pela companhia agradável e alegre, e pelo conhecimento transmitido durante as interpretações dos resultados.

A Dra. Ivone Mulako Sato, pela colaboração nas análises, por sua presteza, educação e conselhos.

A minha família, presente em todos os momentos, compartilhando experiências, felicidades e sempre me incentivando a prosseguir com determinação.

Aos engenheiros Carlos Gaia da Silveira e Elizabeth Sebastiana Ribeiro Somessari, pela atenção, perseverança e colaboração na realização do processamento por radiação das amostras.

Aos prestativos secretários Marcos Cardoso da Silva e Cláudia Regina Nolla nos assuntos administrativos.

Aos colegas de estudos e de laboratório que colaboraram na realização deste trabalho, e compartilharam momentos descontraídos: Adriano dos Santos Oliveira, Alexandre França Velo, Amanda Cristina Ramos Koike, Carla Daruich de Souza, Cauê de Mello Ferraz, Dayane Piffer Luco, Diego Vergaças de Sousa 
Carvalho, Fernando dos Santos Peleias Junior, João Francisco Trencher Martins, Luana dos Santos Andrade, Nelson Mendes Alves, Patrícia Yoko Inamura Takinami, Rejane Daniela de Campos, Renato Cesar Duarte, Rodrigo Crespo Mosca, Rodrigo Kirita e Vanessa Honda Ogihara Silva.

À PETROBRAS e à Fábrica Carioca de Catalisadores pelo fornecimento dos materiais de estudo.

Ao CNPq pelo auxílio financeiro. 


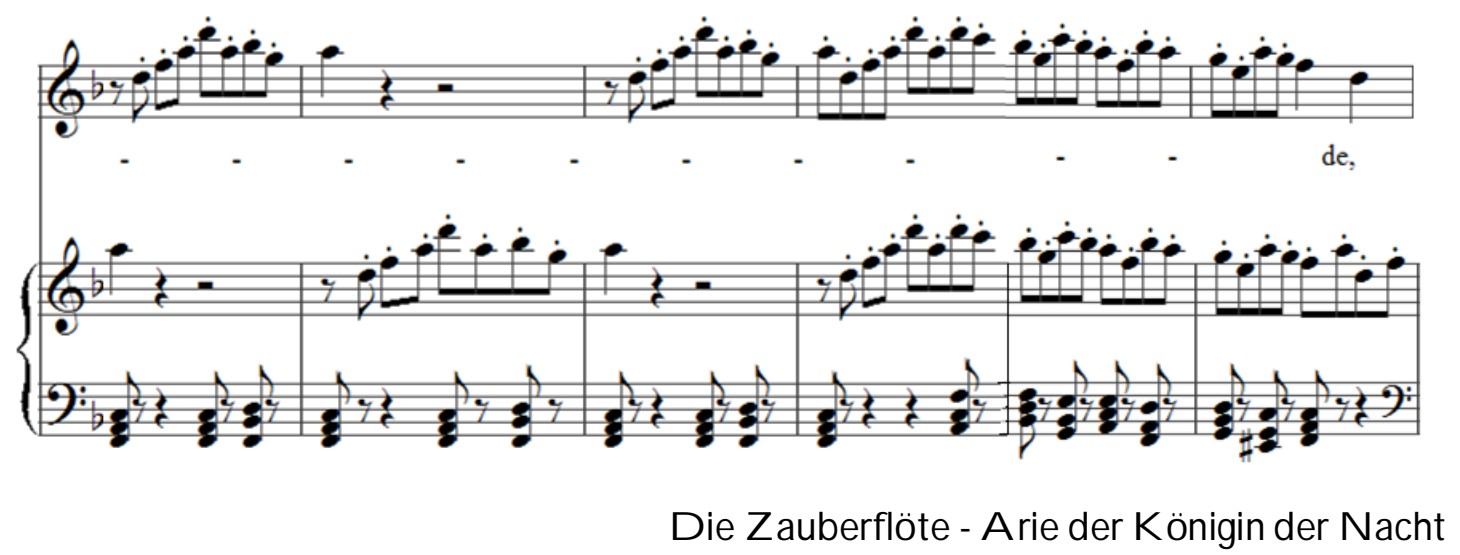

(M ozart) 


\title{
ESTUDO DO EFEITO DA RADIAÇÃO IONIZANTE NA UTILIZAÇÃO DOS CATALISADORES DESATIVADOS DE CRAQUEAMENTO
}

\author{
FERNANDO MANTOVANI KONDO
}

\begin{abstract}
RESUMO
Catalisador é uma substância que altera a velocidade de uma reação. Na indústria do petróleo os catalisadores mais utilizados são os catalisadores de Fluid Catalytic Cracking (FCC) e Hidrocatalytic Cracking (HCC) cada qual utilizado em uma determinada etapa do processo. Esses catalisadores são usados para facilitar a quebra das cadeias moleculares que darão origem a uma mistura de hidrocarbonetos. Contudo, o catalisador perde progressivamente sua atividade, seja pela mudança de sua estrutura molecular original ou pela sua contaminação provenientes de outras moléculas do petróleo. A aplicação das radiações ionizantes (feixe de elétrons e raios gama) nesses catalisadores desativados foi estudada para auxiliar na extração de metais ou terras-raras de alto valor agregado. Nos ensaios realizados com os catalisadores de FCC utilizaram-se das técnicas de irradiação por ${ }^{60} \mathrm{Co}$ e por feixe de elétrons (EB) e tiveram como estudo a extração do lantânio $\left(\mathrm{La}_{2} \mathrm{O}_{3}\right)$, a regeneração e utilização desses catalisadores. Entretanto, o uso da radiação ionizante não contribuiu nesses processos. Já nos catalisadores de HCC foi utilizado a irradiação por feixe de elétrons e como estudo a extração do molibdênio (MoO3). $\mathrm{Na}$ temperatura em torno de $750^{\circ} \mathrm{C}$ nesses catalisadores irradiados do leito inferior obteve-se um rendimento de extração duas vezes maior em comparação aos não irradiados, ou seja de $57,65 \%$ e $26,24 \%$ respectivamente.
\end{abstract}




\title{
STUDY OF THE EFFECT OF IONIZING RADIATION FOR UTILIZATION OF SPENT CRACKING CATALYSTS
}

\author{
FERNANDO MANTOVANI KONDO
}

\begin{abstract}
Catalyst is a substance that changes the rate of a reaction. In the petroleum industry the commonly catalysts are used for Fluid Catalytic Cracking (FCC) and Hidrocatalytic Cracking (HCC), which one applied in a specific stage. These catalysts are used to facilitate the molecular chains cracking which will generate a mixture of hydrocarbons. However, the catalyst gradually loses its activity, either by changing its original molecular structure or by its contamination from other petroleum molecules. The application of ionizing radiation (electron beam and gamma rays) over these spent catalysts was studied to contribute with the extraction of metals or rare-earths of high added-value. Tests carried out with FCC catalysts were used the techniques of ${ }^{60} \mathrm{Co}$ irradiation and electron beam (EB) and had as a subject the extraction of lanthanum (La2O3), regeneration and utilization of these catalysts. However, the use of ionizing radiation has not contributed in these processes. Meanwhile with HCC catalysts the irradiation used was electron beam and had as a subject the extraction of molybdenum (MoO3). In temperature around $750^{\circ} \mathrm{C}$, these irradiated catalysts of the lower region have an extraction yield twice higher compared to non-irradiated ones, in other words $57.65 \%$ and $26.24 \%$ respectively.
\end{abstract}




\section{SUMÁRIO}

\section{Página}

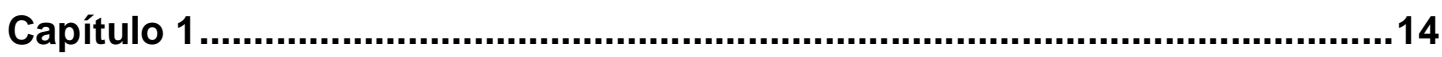

INTRODUÇÃO

Capítulo 2

OBJETIVO

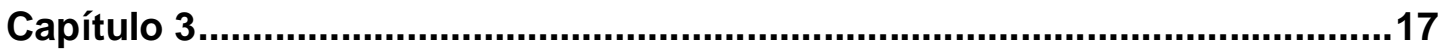

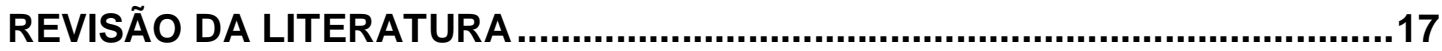

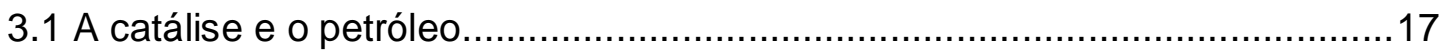

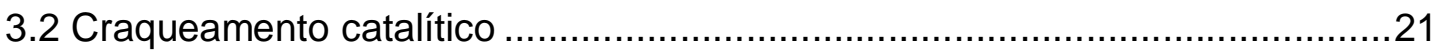

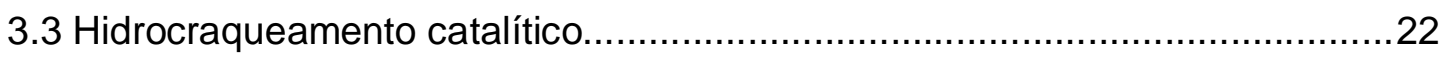

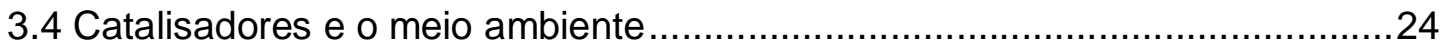

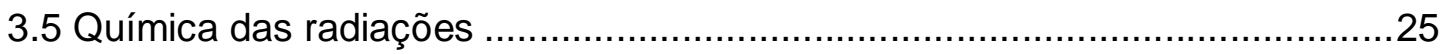

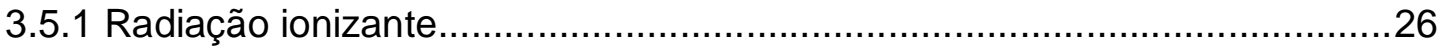

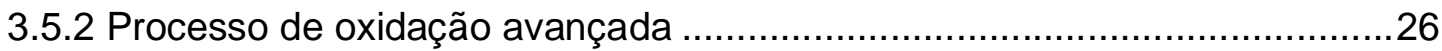

3.6 Catalisadores e o processamento por radiação .............................................27

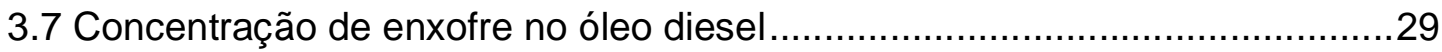

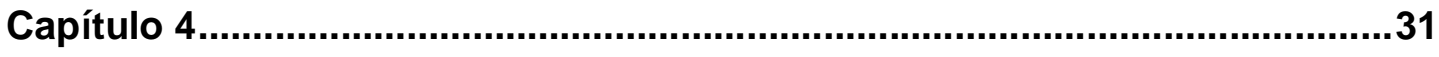

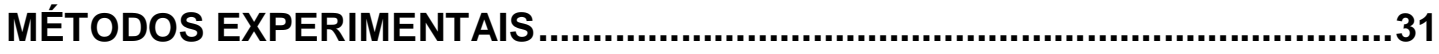

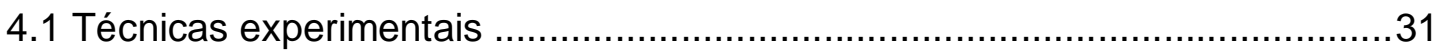

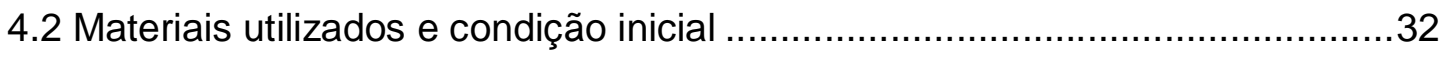

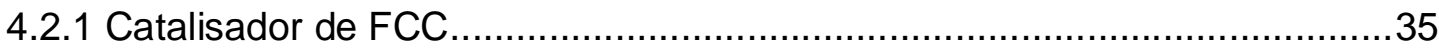

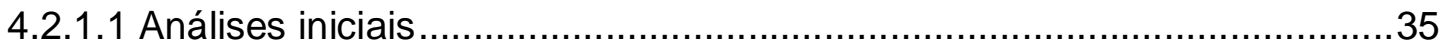

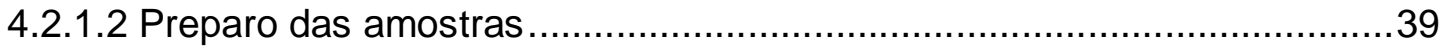

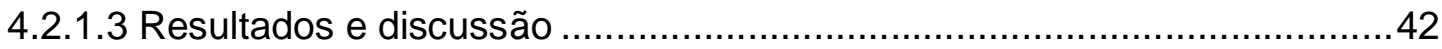

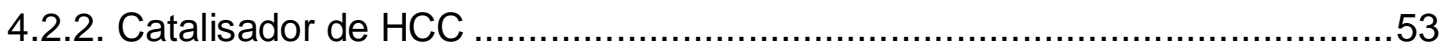

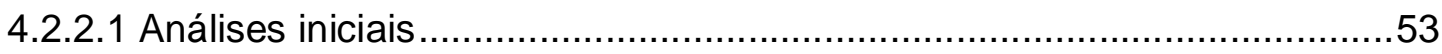

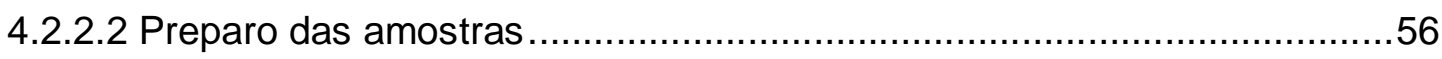

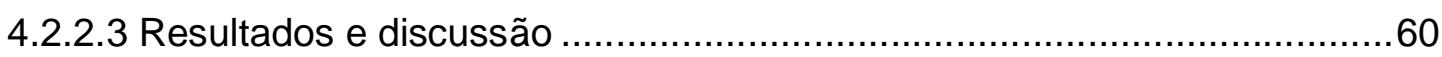




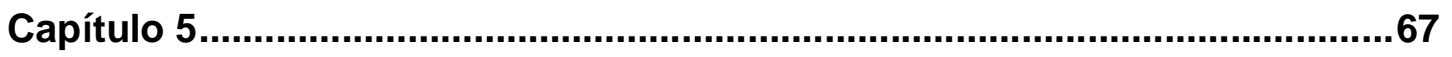

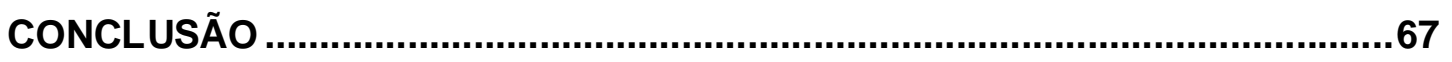

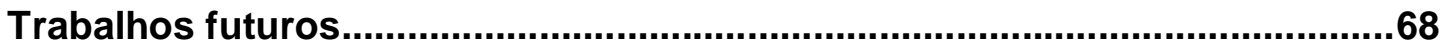

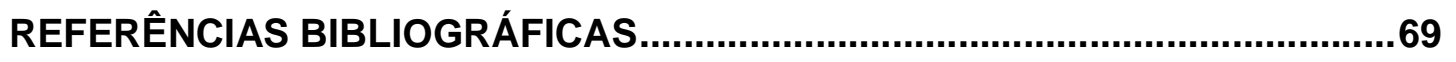




\section{LISTA DE FIGURAS}

\section{Página}

FIGURA 1 - Diagrama geral da refinação do óleo cru até os produtos comercializáveis. 20

FIGURA 2 - Planta tecnológica por feixe de elétrons que utilizava a técnica de Radiation-Thermal Treatment (RTT), para purificação e produção de metais, a partir de resíduos sólidos de catalisadores. 29

FIGURA 3 - Recipientes contendo catalisadores de FCC: a) desativado e b) virgem.

32

FIGURA 4 - Catalisadores de hidrocraqueamento (HCC): a) virgem; b) desativado do leito inferior; e c) desativado do leito superior. 34

FIGURA 5 - Diagrama esquemático da rota de trabalho para o estudo do catalisador de FCC. 35

FIGURA 6 - Microscopia Eletrônica de Varredura (x250) dos catalisadores de FCC:

a) virgem e b) desativado. 37

FIGURA 7 - Difratograma de Raios X do catalisador de FCC virgem. 38

FIGURA 8 - Difratograma de Raios $X$ do catalisador de FCC desativado. 39

FIGURA 9 - Microscopia Eletrônica de Varredura (x250) dos catalisadores de FCC: a) virgem; b) virgem e irradiado a $20 \mathrm{kGy}$; c) desativado; e d) desativado e irradiado a $20 k G y$ por raios gama.

FIGURA 10 - Espectros de infravermelho para os catalisadores de FCC virgem e virgem irradiado (raios gama), nas doses absorvidas de 20 kGy, 50 kGy, 100 kGy e 150 kGy. 44

FIGURA 11 - Espectros de infravermelho para os catalisadores de FCC desativado e desativado irradiado (raios gama), nas doses absorvidas de 20 kGy, 50 kGy, 100 kGy e 150 kGy. 44

FIGURA 12 - Espectro de infravermelho do silicato de alumínio. .45

FIGURA 13 - Espectro de infravermelho da Bohemita. 46

FIGURA 14 - Espectro de infravermelho da caulinita. .46 
FIGURA 15 - Comparação dos difratogramas (DRX) dos catalisadores de FCC virgem, desativado e contaminado com níquel.

FIGURA 16 - Comparação dos difratogramas dos catalisadores de FCC virgem; contaminado com níquel; contaminado, irradiado a 150 kGy por feixe de elétrons e tratado com diclorometano; e desativado. 52

FIGURA 17 - Diagrama esquemático da rota de trabalho para o estudo do catalisador de HCC. .53

FIGURA 18 - Comparação dos difratogramas (DRX) dos catalisadores de HCC virgem e desativados do leito inferior e superior 54 FIGURA 19 - Difratograma das esferas (alumina- $\alpha$ ) encontradas no catalisador de HCC do leito superior. .55 FIGURA 20 - Sistema de aquecimento do catalisador de HCC com controle de temperatura.

FIGURA 21 - Sistema de aquecimento do catalisador de HCC e irradiação simultânea com feixe de elétrons de 1,3 MeV, no IPEN-CNEN/SP. .58

FIGURA 22 - Curva de calibração para medição de temperatura. 60 FIGURA 23 - Gráfico comparativo dos tratamentos TT e RTT nos catalisadores de HCC desativado do leito inferior. .64 FIGURA 24 - Gráfico comparativo dos tratamentos TT e RTT nos catalisadores de HCC desativado do leito superior. 64 FIGURA 25 - Processamento do catalisador de HCC desativado (leito inferior) por RTT: a) cadinho de alumina e b) cristal formado após a irradiação por feixe de elétrons de 1,3 MeV. 65

FIGURA 26 - Difratograma de Raios X (DRX) do cristal formado no processamento do catalisador de HCC desativado (leito inferior) por RTT. 66 


\section{LISTA DE TABELAS}

\section{Página}

TABELA 1 - EDX dos catalisadores virgem e desativado de FCC

TABELA 2 - EDX dos catalisadores de hidrocraqueamento (HCC): virgem e desativados do leito inferior e superior

TABELA 3 - Tamanho médio das partículas do catalisador de FCC.

TABELA 4 - EDX dos catalisadores de FCC desativado e desativado irradiado por feixe de elétrons (30,36 MGy), após tratamento químico.

TABELA 5 - EDX do catalisador de FCC contaminado com níquel e irradiado com feixe de elétrons, nas doses absorvidas de 20 kGy e 150 kGy.

TABELA 6 - EDX dos catalisadores de FCC contaminados com níquel, refluxados (60 min e $220 \mathrm{~min}$ ) e irradiado com doses de 20 kGy por feixe de elétrons. .50

TABELA 7 - EDX dos catalisadores de HCC desativados do leito inferior e superior tratados termicamente.

TABELA 8 - EDX dos catalisadores de HCC desativados do leito inferior e superior tratados termicamente aliada a irradiação com feixe de elétrons (EB) e dose de 30,36 MGy. 62

TABELA 9 - Valores comparativos para os tratamentos TT e RTT aplicados aos catalisadores de HCC desativados do leito inferior e superior. 63 


\section{Capítulo 1}

\section{INTRODUÇÃO}

Qualquer um que considere catálise heterogênea como um aspecto da ciência de superfície e estude o comportamento das moléculas em uma superfície catalítica não é suscetível de ser atraído pela ideia de um bombeamento de resíduo de petróleo ao longo de superfícies catalíticas limpas e cuidadosamente caracterizadas. Catalisadores projetados para dessulfurar frações de destilação de petróleo (Co-Mo/alumina ou Ni-Mo/alumina) perderão a sua atividade em alguns dias, quando em contato com um resíduo de petróleo, nas condições em que poderiam funcionar bem durante vários anos em destilação comercial de hidroprocessamento (Oelderik, 1989).

A catálise foi praticada pela sociedade durante muitos anos sem que tivesse o conhecimento dela, como na fabricação de vinhos e cervejas. Atualmente, os catalisadores são usados para dinamizar a forma com que produzimos materiais em nosso ambiente, sendo que seu impacto é substancial. Indústrias químicas e refinarias de petróleo são interconectadas com a indústria de catalisadores (Armor, 2011).

A concentração do enxofre no óleo varia de 0,2\% (Golfo Pérsico) a 4\% (México e Venezuela). O enxofre advém de mercaptanas, dissulfetos e ácido sulfídrico que lixiviaram para o óleo. Óleos com elevada concentração de enxofre têm maior impacto nas operações da refinaria, em função dos seus efeitos corrosivos. As mercaptanas têm limite olfativo de partes por bilhão (ppb) e representam um sério problema ambiental (Burgess, 1997). 
Por muitos anos, utilizou-se ácido sulfúrico para extrair compostos à base de enxofre, gerando lodo ácido, que exigia tratamento prévio à disposição. $\mathrm{O}$ ácido sulfúrico foi substituído por ácido fluorídrico. Esses métodos ácidos estão sendo substituídos por técnicas catalíticas usando níquel, cobalto e catalisadores à base de molibdênio em grânulos, pellets ou pó: dessulfuração catalítica ou hidrotratamento (Burgess, 1997).

O catalisador de FCC é composto, basicamente, por óxido de alumínio $\left(\mathrm{Al}_{2} \mathrm{O}_{3}\right)$ e óxido de silício $\left(\mathrm{SiO}_{2}\right)$. O processo de $\mathrm{FCC}$ tem como principal objetivo a produção de nafta de alta octanagem e Gás Liquefeito do Petróleo (GLP). Já o catalisador de HCC é constituído de um suporte de sílica-alumina $\left(\mathrm{SiO}_{2}-\mathrm{Al}_{2} \mathrm{O}_{3}\right)$, no qual se depositam óxidos de níquel-molibdênio (NiO-MoO). O processo de HCC ocorre na presença do catalisador, altas temperaturas e pressões e presença de grandes volumes de hidrogênio (Abadie, 2002).

Dada a crescente importância dos problemas ambientais e das medidas relativas à proteção do meio ambiente, as quais estão cada vez mais severas, as operações de descarte dos catalisadores desativados ocupam cada vez mais a atenção de pesquisadores e técnicos. Eles são poluentes em potencial, em função dos consideráveis teores de metais pesados existentes e à correspondente contaminação de solos, plantas e lençóis freáticos.

Óleos crus são misturas coloidais de diversos hidrocarbonetos. Variam de condensados leves, altamente voláteis e de baixas massas molares a pesadas, densos e altamente viscosos (óleo pesado e betume) com uma tendência de elevada massa molar. Óleos pesados e crus normalmente possuem mais enxofre, nitrogênio e metais e são vendidos com um desconto significativo aos óleos leves crus, por exemplo, os óleos West Texas Intermediate (National Energy Technology Laboratory, 2005).

Pesquisas em radiação aplicadas ao petróleo vem sendo estudadas pelas maiores companhias petrolíferas, desde 1950. Amplas variedades de fontes radioativas a fontes de alta energia estão sendo exploradas, tais como, emissão de nêutrons, elétrons, raios gama, partículas beta e produtos de fissão. 


\section{Capítulo 2}

\section{OBJETIVO}

O presente trabalho tem como objetivo estudar os efeitos das radiações ionizantes (raios gama e feixe de elétrons) nos catalisadores desativados de Fluid Catalytic Cracking (FCC) e Hidrocatalytic Cracking (HCC) para se viabilizar a extração de elementos químicos de alto valor agregado. No caso dos catalisadores de FCC, têm-se como meta a extração do lantânio $\left(\mathrm{La}_{2} \mathrm{O}_{3}\right)$, a regeneração e utilização dos catalisadores; já para o catalisador de HCC a extração do molibdênio $\left(\mathrm{MoO}_{3}\right)$. 


\section{Capítulo 3}

\section{REVISÃO DA LITERATURA}

\subsection{A catálise e o petróleo}

A primeira etapa de destilação ocorre a pressão atmosférica, seguindose uma série de estágios, com a retirada de água e dessalinização, onde o óleo é processado em caldeiras para a vaporização parcial. É aquecido entre $340{ }^{\circ} \mathrm{C}$ a $345^{\circ} \mathrm{C}$ antes do fracionamento. O óleo aquecido entra na torre de destilação em duas frações: o vapor começa a subir enquanto o petróleo bruto reduzido não vaporizado é retirado pelo fundo da torre para o processamento de uma unidade de destilação a vácuo. O vapor resfria-se à medida que ascende, e as fracções de elevado ponto de ebulição se condensam nos pratos mais baixos. Esse vapor contém alta porcentagem de hidrocarbonetos recuperáveis com líquido.

O gás (gasóleo) proveniente da destilação simples e a vácuo pode ser processado no craqueamento catalítico para produzir olefinas, diolefinas, hidrocarbonetos aromáticos e nafteno. O óleo pesado e o gasóleo vão para 0 craqueador catalítico, entre $470{ }^{\circ} \mathrm{C}$ a $550{ }^{\circ} \mathrm{C}$ e de $68,9 \mathrm{kPa}$ a $206,7 \mathrm{kPa}$ (10 Psi a 30 Psi), e por meio da interação com os catalisadores (zeólitas, alumina-silicatos, argila em pellets ou pó), $50 \%$ a $80 \%$ é craqueado em gasolina e em óleo combustível leve e pesado.

Uma característica da operação é a formação de elevada porcentagem de compostos aromáticos. A superfície do catalisador fica recoberta de depósitos de carbono leve e deve ser regenerada mediante aquecimento entre $540 \stackrel{\circ}{\mathrm{C}}$ a $650^{\circ} \mathrm{C}$ em contato com o ar. 
Os destilados e o querosene cru são tratados na planta de hidrogenação para conversão destas matrizes em produtos de ponto de ebulição mais baixos. No primeiro estágio da operação, a $300{ }^{\circ} \mathrm{C}$ e pressão de $20.684,3 \mathrm{kPa}$ (3.000 Psi), enxofre e nitrogênio são removidos. O craqueamento ocorre no segundo estágio, no berço catalítico de cobalto-molibdênio ou cobalto-níquel, em temperatura de $315^{\circ} \mathrm{C}$ e pressão de $10.342,1 \mathrm{kPa}(1.500 \mathrm{Psi})$. Produtos apresentando larga faixa de ebulição são formados e podem ser fracionados em produtos úteis: querosene, óleo diesel e óleo combustível leve.

A nafta pesada, contendo naftenos e parafinas, é processada por meio de unidades de reforma catalítica que convertem o material a hidrocarbonetos aromáticos. Esse processo é conduzido em temperatura elevada, utilizando-se como catalisador a platina, o paládio ou o níquel-cobalto. O produto é utilizado diretamente na refinaria para melhorar a octanagem da gasolina ou vendido para petroquímicas (Burgess, 1997).

Em teoria, as operações unitárias da refinação do óleo parecem simples; na pratica, são bastante complicadas. Uma refinaria consiste em uma ou mais unidades, além da unidade de destilação, que compreendem: forno, calefator de óleo, torre de fracionamento, retificadores a vapor, equipamento de troca térmica, resfriadores e condensadores; tambores de acumulo na unidade; agitadores descontínuos ou unidade a tanque fechado de operação continua (trata os produtos e remove compostos nocivos de enxofre e atribui aos produtos uma cor aceitável); filtros; tanques de homogeneização e mistura da carga; sistema de dutos para recepção do óleo cru; bombas para transferência dos óleos e para carga e embarque dos produtos; tanques de estocagem do suprimento de óleo e dos produtos acabados; sistema de recuperação de vapor e diversos auxiliares.

Deve-se incluir também uma usina para geração de vapor e, possivelmente, de luz e eletricidade. Na operação dessa grande entidade, os balanços de calor, de energia e de massa são da maior importância para se manterem rígidos controles de todas as etapas de processamento do óleo. 
Na FIG. 1 é mostrada uma representação esquemática que exemplifica um sistema básico de refino, com a separação do óleo cru nas diversas frações e o tratamento subseqüente de cada fração; os vários produtos são removidos da torre de óleo cru, conforme diagrama (Shreve, 1977). 


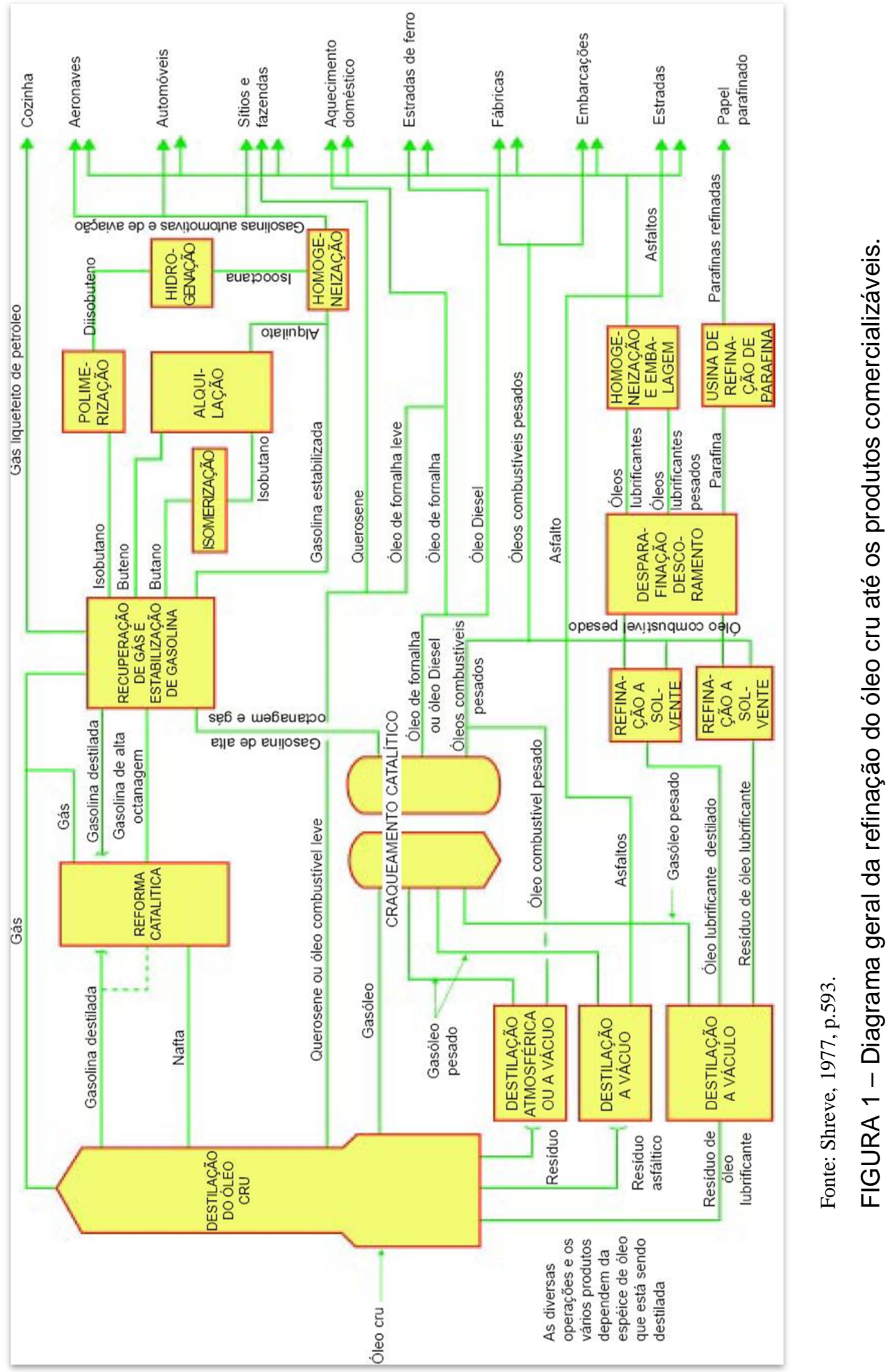




\subsection{Craqueamento catalítico}

O craqueamento catalítico é um processo de quebra molecular. Sua carga é uma mistura de gasóleo de vácuo e óleo desasfaltado, que, submetida a condições bastante severas em presença do catalisador, é transformada em várias outras frações mais leves, produzindo gás combustível, gás liquefeito, nafta, gasóleo leve (óleo diesel de craqueamento) e gasóleo pesado de craqueamento (óleo combustível). As reações produzem também coque, que se deposita no catalisador e é queimado quando na regeneração desse último, gerando gás de combustão, de alto conteúdo energético, usado na geração de vapor de água de alta pressão.

O processo surgiu um pouco antes da segunda guerra mundial, tomando um notável impulso com este conflito, em face à grande necessidade dos aliados em relação a suprimentos de gasolina e material petroquímico para suas tropas. Com o fim da guerra, o craqueamento catalítico firmou-se, principalmente, em função da produção de nafta, em maior quantidade, de melhor qualidade e com custos de produção bem inferiores aos outros processos existentes na época.

É um processo destinado, por excelência, à produção de nafta de alta octanagem, o derivado que aparece em maior quantidade, de $50 \%$ a $65 \%$ do volume em relação à carga processada. $O$ segundo derivado em maior proporção é o gás liquefeito de petróleo (GLP), de $25 \%$ a $40 \%$ do volume em relação à carga. Em menores rendimentos, temos também o óleo diesel de craqueamento Light Cycle Oil (LCO), o óleo combustível de craqueamento (óleo decantado ou clarificado), o gás combustível e o gás sulfídrico $\left(\mathrm{H}_{2} \mathrm{~S}\right)$. O coque gerado é depositado no catalisador e queimado na regeneração.

A grande necessidade nacional de produção de GLP e, principalmente, de gasolina até o final dos anos setenta, fez com que a PETROBRAS instalasse este processo em todas as suas refinarias. O craqueamento catalítico, também conhecido como Fluid Catalytic Cracking (FCC), é um processo de grande versatilidade e de elevada rentabilidade no quadro atual do refino, embora seja também uma unidade de alto investimento para sua implantação (Abadie, 2002). 
O modelo de unidade craqueadora a catalisador fluidizado Orthflow da M.W.Kellogg Co. (Hydrocarbon Process.) realiza a reação, separação do catalisador, regeneração e circulação do catalisador num único conversor (Zenz, 1974).

O sistema convencional de regeneração do catalisador é composto por algumas etapas. Inicialmente, o catalisador gasto pelas reações de craqueamento sai do reator e passa pelo retificador, onde é tratado a vapor de água, para remoção dos produtos de craqueamento e do óleo arrastado pelo catalisador descendente. O catalisador do retificador cai então, em fase densa, pelas colunas (standpipes) de catalisador gasto, passa por válvulas de controle e entra no leito do regenerador. No regenerador o coque depositado sobre o catalisador durante a reação é queimado, usando-se ar injetado. Os gases de combustão passam subindo pelo leito fluido, chegam a uma zona de separação e passam, depois, por diversos ciclones, usualmente dois ou três (Shreve, 1977).

\subsection{Hidrocraqueamento catalítico}

O hidrocraqueamento catalítico, também conhecido como Hidrocatalytic Cracking ( $\mathrm{HCC})$ é um processo que consiste na quebra de moléculas existentes na carga de gasóleo por ação conjugada do catalisador, altas temperaturas e pressões, e na presença de hidrogênio. Ao mesmo tempo em que ocorrem as quebras, simultaneamente acontecem reações de hidrogenação do material produzido. É um processo que concorre, portanto, com o craqueamento catalítico fluido (Abadie, 2002).

O HCC surgiu na década de cinqüenta, atingindo seu apogeu no início dos anos setenta, pouco antes da crise do petróleo. Com o aumento do preço do óleo, de seus derivados e do preço do gás natural, principal matéria-prima para obtenção do hidrogênio, este também teve seu preço extremamente elevado, afetando bastante a rentabilidade do processo. Isto fez com que houvesse retração na implantação de novas unidades, tanto nos Estados Unidos, quanto nos demais países (Abadie, 2002). 
A grande vantagem do hidrocraqueamento é sua extrema versatilidade. Pode operar com cargas que variam, desde nafta, até gasóleos pesados ou resíduos leves, maximizando a fração que desejar o refinador - desde gasolina, até gasóleo para craqueamento - obviamente em função da carga (Abadie, 2002).

Outra grande vantagem constatada é a qualidade das frações no que diz respeito aos contaminantes. Diante das severíssimas condições em que ocorrem as reações, praticamente todas as impurezas, como compostos de enxofre, nitrogênio, oxigênio e metais, são radicalmente reduzidas ou eliminadas dos produtos (Abadie, 2002).

A desvantagem do processo consiste nas drásticas condições operacionais. Elevadas pressões e temperaturas são usadas, o que obriga a utilização de equipamentos caros e de grande porte, com elevado investimento, não só pelo que já foi exposto, mas também pela necessidade de implantação de uma grande unidade de geração de hidrogênio, cujo consumo no processo é extremamente alto (Abadie, 2002).

Os catalisadores empregados no hidrocraqueamento devem possuir características de craqueamento e de hidrogenação, simultaneamente. A alumina $\left(\mathrm{Al}_{2} \mathrm{O}_{3}\right)$ acidificada ou combinada à sílica $\left(\mathrm{SiO}_{2}\right)$ proporciona reações de quebra de cadeias lineares e isomerização, sendo a responsável pelas reações de craqueamento. A sílica-alumina é capaz de romper ligações carbono-carbono de cadeias abertas ou mesmo naftênicas, porém não demonstra eficiência para a abertura de anéis aromáticos (Abadie, 2002).

Estes catalisadores são bifuncionais e são capazes de craquear hidrocarbonetos de alta massa molar e hidrogenar insaturados que são formados durante a fase de craqueamento (Ali et al., 2002). Estes catalisadores costumam conter, ainda, zeólitas em sua composição, visando conferir-Ihes acidez adequada (Cabral, 2005).

Na prática, os reatores de hidrocraqueamento utilizam catalisadores de óxidos de níquel - molibdênio (NiO-MoO) ou óxidos de níquel - tungstênio $\left(\mathrm{NiO}-\mathrm{WO}_{3}\right)$, depositados em suporte de sílica-alumina $\left(\mathrm{SiO}_{2}-\mathrm{Al}_{2} \mathrm{O}_{3}\right)$. Esse tipo de 
catalisador é suscetível a envenenamento por compostos cíclicos nitrogenados e metais, o que altera sua atividade (capacidade de conversão dos reagentes em produtos) e seletividade (capacidade de dirigir uma dada reação no sentido de produzir um determinado produto). Todos os processos comerciais de hidrocraqueamento são relativamente semelhantes. Diferem essencialmente entre si por detalhes de concepção, em função do tipo de catalisador utilizado (Abadie, 2002).

\subsection{Catalisadores e o meio ambiente}

Dada a crescente importância dos problemas ambientais e das medidas relativas à proteção do meio ambiente, as quais estão cada vez mais severas, as operações de descarte de catalisadores desativados ocupam cada vez mais a atenção de pesquisadores e técnicos. Eles são poluentes em potencial em função dos consideráveis teores de metais pesados existentes e à correspondente contaminação de solos, plantas e lençóis freáticos. A título de exemplo, a Agência Norte-Americana de Proteção ao Meio Ambiente (EPA) reafirmou em 1996 o conceito de catalisador descartado como resíduo perigoso (Bader, 1996; Lima, 1998).

Estudo como de Júlio Afonso (Afonso et.al., 2003) mostra como a composição de um catalisador industrial desativado pode contaminar o meio ambiente, mesmo após um tratamento drástico de oxidação a alta temperatura.

No trabalho de Júlio Afonso (Afonso et. al., 2006), assim como de Busnardo (Busnardo, 2005) expõem a recuperação de metais de catalisadores de hidrorrefino, $\mathrm{NiMo} / \mathrm{Al}_{2} \mathrm{O}_{3}$ e $\mathrm{CoMo} / \mathrm{Al}_{2} \mathrm{O}_{3}$, usados via fusão com $\mathrm{KHSO}_{4}$, no qual se segue o procedimento de fusão e processamento da amostra a ponto de se obter uma solução com os metais provenientes dos catalisadores, demonstrando não apenas o estudo da viabilidade técnica da recuperação de metais de catalisadores gastos, mas também inserindo no contexto a preservação do meio ambiente. Em outro estudo, também realizado por Júlio Afonso (Afonso et.al., 1997) foi realizada a extração dos metais via ácido oxálico, oxalato do amônio, hidróxido de amônio e 
misturas desses dois últimos reagentes, e após todo um processamento os metais foram analisados via espectrometria de absorção atômica/emissão de chama ou por fluorescência de raios $\mathrm{X}$, além da cromatografia de íons para detecção de íons.

Em trabalhos realizados pelo Instituto Superior Técnico, em Lisboa foram estudadas a prevenção da desativação do zeólito pelo coque (Guisnet, 2009). Abordando-se as taxas de desativação e o estudo do coque, algumas regras foram propostas para se minimizar o efeito da desativação, assim como a desativação nos catalisadores de FCC (Cerqueira, 2008), que é discutido pelo ponto de vista fundamental e aplicado a desativação do zeólito HY e dos catalisadores de FCC. Ambos os trabalhos visam alertar o estudo do coque como razão da desativação, e sua melhor compreensão colabora para menor desativação, sendo que para as caracterizações do coque ambos citam a ressonância magnética nuclear (RMN), espectroscopia Raman e infravermelho, além de espectroscopia de perda de energia do elétron (EELS), cromatografia gasosa acoplado ao detector de massas (GC/MS), e ionização e dessorção a lazer assistida por matriz com analisador de massas por tempo de vôo (LD-MALDI-TOF-MS).

\subsection{Química das radiações}

A química das radiações é o estudo dos efeitos químicos quando o material é submetido a radiação ionizante. O termo radiação ionizante em um senso amplo é aplicado para os fótons e partículas que possuem energia suficiente para ionizar as moléculas, de 10 eV a vários milhões de elétron-Volts (eV), assim como partículas carregadas, elétrons, pósitrons, íons pesados acelerados, entre outros. O resultado da absorção da energia é a quebra ou o rearranjo das ligações químicas. Fótons de altas energias podem ser absorvidos pelos núcleos e causar reações nucleares. Esse é o campo da física nuclear e da química nuclear ou radioquímica (Hummel, 1992; Wojnárovits, 2003). 


\subsubsection{Radiação ionizante}

Todas as formas de radiação ionizante interagem com a matéria transferindo sua energia para átomos e moléculas presentes. Na primeira fase de interação ocorre um efeito físico, que consiste na ionização e excitação dos átomos, resultante da troca de energia entre a radiação e a matéria. Esse efeito processa-se num intervalo de tempo muito curto na ordem de $10^{-13}$ a $10^{-12}$ segundos. $\mathrm{Na}$ segunda fase de interação, ocorrem os efeitos químicos, ou seja, ruptura de ligações nas moléculas e formação de radicais livres. Esta ação química processase num intervalo de tempo estimado em $10^{-9}$ segundos (Duarte, 1999).

Os efeitos químicos de interação da radiação com a matéria dar-se-á por dois mecanismos que são o direto, no qual a radiação interage diretamente na molécula em questão e o efeito indireto, no qual a radiação interage com a molécula de água, gerando espécies químicas muito reativas e difusíveis e que vão interagir no material estudado (Duarte, 1999).

Os processos de transferência de energia para a matéria são diferentes para radiação eletromagnética (raios gama e raios $\mathrm{X}$ ), e partículas carregadas (elétrons de alta energia e partículas com cargas positivas). Os fótons com energia acima de $10 \mathrm{MeV}$, podem interagir no núcleo do átomo e ejetar um próton ou nêutron (reação nuclear), induzindo radioatividade no material absorvedor. Esta é a razão pela qual aceleradores de elétrons comerciais são limitados a energia de $10 \mathrm{MeV}$ e máquinas de raios X a $5 \mathrm{MeV}$ (Duarte, 1999).

\subsubsection{Processo de oxidação avançada}

No processo de oxidação avançada (POA) utilizando radiação ionizante empregam-se, basicamente, dois tipos de irradiadores: aqueles que utilizam radioisótopos artificiais emissores de raios gama, tais como, cobalto-60 e césio-137, e os aceleradores industriais de elétrons (Duarte, 1999).

As fontes de radiação gama requerem blindagens especiais de concreto com paredes espessas e são usadas principalmente na esterilização de produtos médicos e irradiação de alimentos, onde a penetração maior da radiação é uma 
vantagem. Os aceleradores industriais de elétrons são geralmente preferidos como fonte de radiação para aplicações ambientais (Duarte, 1999).

As vantagens do acelerador industrial de elétrons são as taxas de dose altas, rendimento maior de energia, licenciamento similar às máquinas de raios $\mathrm{X} e$ o sistema liga-desliga que cessa a emissão da radiação ionizante. As desvantagens são a penetração baixa dos elétrons no material e a necessidade de operadores especializados (Duarte, 1999).

\subsection{Catalisadores e o processamento por radiação}

O processamento de óleos com alto teor de enxofre consome catalisadores de hidrocraqueamento em grandes quantidades. Apesar da possível regeneração dos catalisadores de hidrogenação a base de $\mathrm{Ni}(\mathrm{Co})$ e óxidos de $\mathrm{Mo}$, perdas significativas dos catalisadores acontecem em função de sua desativação irreversível. Há uma ampla variedade de métodos para extração de componentes inativos, tais como, extração aquosa e amônia-aquosa de Mo, que permite a separação de compostos $\mathrm{Ni}(\mathrm{Co})$ e $\mathrm{Mo}$, e a extração de $90 \%$ em massa, aproximadamente, de $\mathrm{Mo}$ na forma de $\mathrm{MoO}_{3}$, e tratamento alcalino (isolamento do Mo de até $80 \%$ em massa), independentemente da concentração inicial e estrutura do composto. A purificação completa dos óxidos de C e S (de até 99\% em massa) foi primeiramente realizada utilizando-se a técnica do Radiation-Thermal Treatment (RTT) e a possibilidade de extração de metais por irradiação foi notada por Solovetskii, Yu.I. Problemy Dezaktivatsii Katalizatorov (Lunin et al., 1993).

Experimentalmente, amostras de extrudados de catalisadores contendo Mo, (4 mm a 8 mm de comprimento por $2 \mathrm{~mm}$ a $5 \mathrm{~mm}$ de diâmetro) com composição inicial de 4,9\% em massa de $\mathrm{Ni}(\mathrm{Co}), 12 \%$ em massa de Mo, 20\% em massa de $\mathrm{C}$, $5 \%$ em massa de $\mathrm{S}$ e $\mathrm{Al}_{2} \mathrm{O}_{3}$ restante foram submetidas a técnica de $\mathrm{RTT}$ a 1,2 MeV de energia do feixe, utilizando-se um acelerador industrial de elétrons construído pelo Institute of Nuclear Physics, Siberian Branch, Russian Academy of Sciences. O resultado para o RTT (irradiação por feixe de elétrons de até 2,0 MeV, em 30 minutos) no desativado de $\mathrm{Ni}(\mathrm{Co})-\mathrm{Mo} / \mathrm{Al}_{2} \mathrm{O}_{3}$ é similar ao tratamento térmico 
convencional entre $540^{\circ} \mathrm{C}$ a $650^{\circ} \mathrm{C}$. Inicialmente o RTT dessorve compostos de carbono e enxofre, os quais são intensamente decompostos pela radiação ionizante (Lunin et al., 1993).

Estudos feitos por A.Yu. Adzhiev com a aplicação por feixes de elétrons de média energia (até 2,0 MeV) no tratamento de catalisadores de $\mathrm{Zn}-\mathrm{Cr}$-Fe e na oxidação direta do gás sulfídrico para enxofre, mostram que em tal tratamento são formadas estruturas de espinélios ativados, com um tempo mínimo de irradiação. No tratamento de catalisadores contaminados por coque, notou-se que o coque depositado foi removido de forma eficiente, assim como os subprodutos de enxofre. Observou-se uma transição reversível das fases para os catalisadores, relacionada à formação do sulfeto de ferro (Adzhiev et al., 1991).

Nesse mesmo assunto, a obtenção e a purificação de metais por intermédio da irradiação por feixe de elétrons também consta no estudo de Yu.I. Solovetskii (Solovetskii et al., 1998), no qual a irradiação com energias de 1,2 MeV a 1,6 MeV em altas temperaturas foi usada para produção de Pt, Pd, Mo, Co, Cu e $\mathrm{Ni}$ provenientes de catalisadores de reforma desativados a base $\operatorname{de} \operatorname{Pt}(\mathrm{Pd})$, catalisadores de hidrodesulfuração a base de sulfeto de molibdênio e resíduos de catalisadores de hidrogenação.

Estudou-se também a indução da decomposição por intermédio da radiação ionizante em catalisadores de sulfeto de $\mathrm{Ni}(\mathrm{Co})-\mathrm{Mo} / \mathrm{Al}_{2} \mathrm{O}_{3}$ e fragmentos orgânicos de resíduos de catalisadores de hidrogenação. A distribuição dos produtos de radiólise foi estudada em função do tempo (até $1 \mathrm{~h}$ ) e da temperatura $\left(297^{\circ} \mathrm{C}\right.$ a $\left.1.127^{\circ} \mathrm{C}\right)$. Projetou-se a primeira unidade tecnológica com feixe de elétrons, que utilizava a técnica de Radiation-Thermal Treatment (RTT), para purificação e produção de alguns metais a partir de resíduos sólidos, mostrada na FIG. 2 (Solovetskii et al., 1998). 


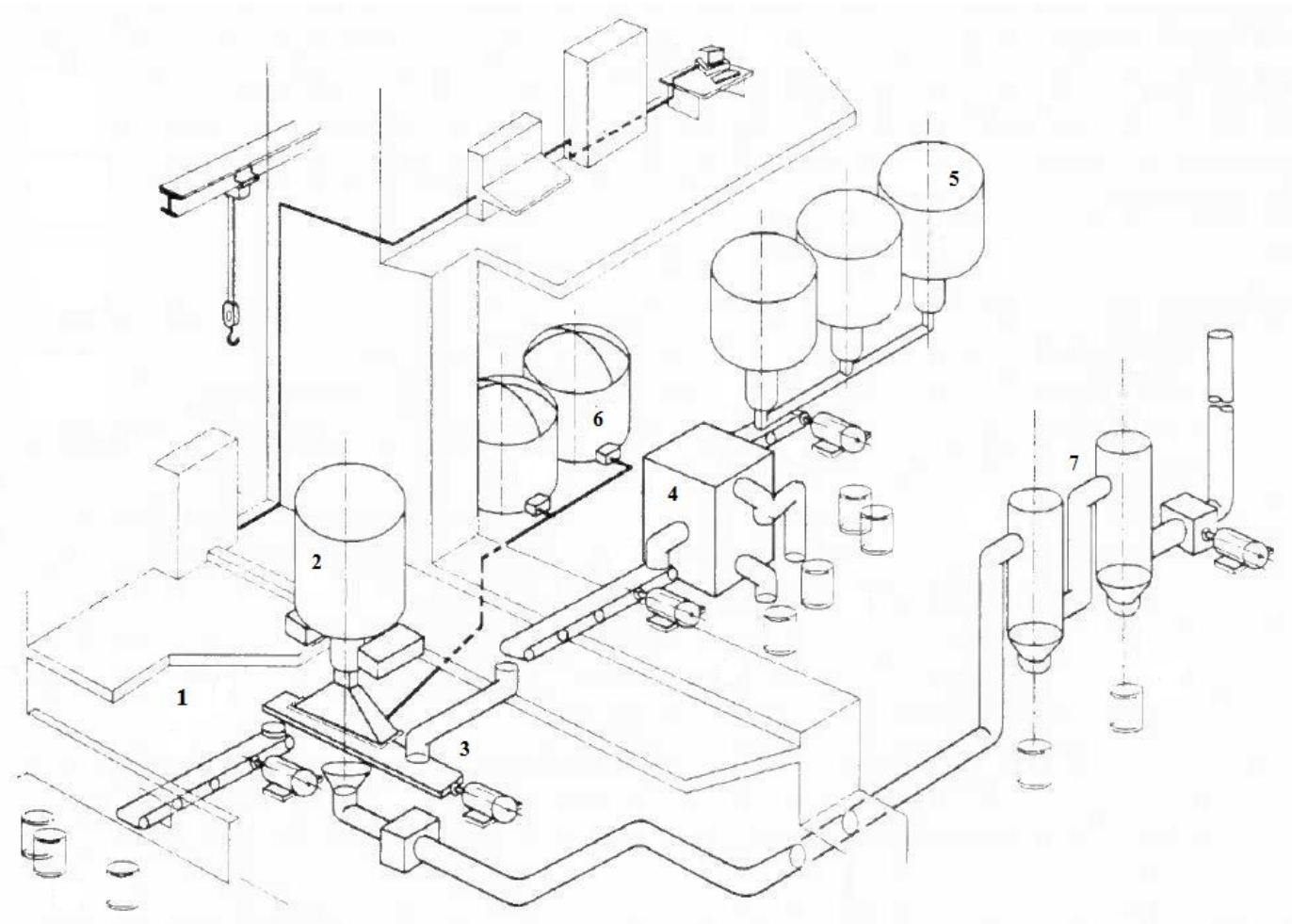

1. Local de irradiação; 2. Acelerador industrial de elétrons com esteira transportadora, para o catalisador mover-se com velocidade controlada;

3. Alimentador; 4. Dispersor; 5. Reservatórios contendo o catalisador;

6. Gás contendo íon de amônio de purificação adicional, para remoção do enxofre; e 7. Descarte do sulfato de amônio na atmosfera

Fonte: Solovetskii et al., 1998.

FIGURA 2 - Planta tecnológica por feixe de elétrons que utilizava a técnica de Radiation-Thermal Treatment (RTT), para purificação e produção de metais, a partir de resíduos sólidos de catalisadores.

\subsection{Concentração de enxofre no óleo diesel}

A Resolução 315 do Conselho Nacional do Meio Ambiente (CONAMA) (Ministério do Meio Ambiente, 2002), assinada em 2002, impõe um limite de 50 partes por milhão (ppm) de enxofre para o óleo diesel (S50) e deveria entrar em vigor em janeiro de 2009. Tal resolução não foi cumprida pela PETROBRAS e pelos fabricantes de veículos (Salomon, 2008). 
O novo cronograma para a redução da concentração de enxofre no diesel foi proposto ao Conselho Nacional do Meio Ambiente (CONAMA) pelo então Ministro do Meio Ambiente, Carlos Minc. Ele afirmou ter obtido o aval do ex-presidente Luiz Inácio da Silva para a proposta de adotar o diesel menos poluente - o S10 (com dez partes por milhão) em 2012 (Salomon, 2008).

Em 2008, a concentração no óleo diesel brasileiro era de 500 ppm nas regiões metropolitanas e de 2.000 ppm nas áreas rurais. Na Europa, essa concentração é de 10 ppm e nos Estados Unidos, 15 ppm. A proposta sugeria que a partir de outubro o teor de enxofre no óleo diesel utilizado no interior do País passaria de 2.000 ppm para 1.800 ppm. Nas regiões metropolitanas de São Paulo, Rio, Curitiba, Fortaleza, Recife e Belém, cairia de 500 ppm para 50 ppm - mas sem prazo para a execução das mudanças (EcoDebate, 2008).

Atualmente, as distribuidoras já fornecem diesel S10 (10 ppm) no mercado nacional, para utilização nos ônibus e caminhões em circulação no Brasil. 


\section{Capítulo 4}

\section{MÉTODOS EXPERIMENTAIS}

\subsection{Técnicas experimentais}

Para a realização dos procedimentos experimentais, algumas técnicas foram utilizadas na avaliação e no estudo dos catalisadores de Fluid Catalytic Cracking (FCC) e Hidrocatalytic Cracking (HCC).

Para a caracterização e análise elementar utilizou-se a técnica da espectrometria de fluorescência de raios X por energia disperssiva (EDX), por meio de equipamentos disponíveis no Centro de Química e Meio Ambiente (CQMA) e no Centro de Ciências e Tecnologia de Materias (CCTM), ambos do IPEN-CNEN/SP.

Os catalisadores foram estudados e observados por microscopia eletrônica de varredura (MEV), utilizando-se um microscópio Hitachi Tabletop TM-3000. No âmbito de se estudar e compreender as fases cristalinas do catalisador e suas modificações foram realizadas análises de difração de raios $X$ (DRX) utilizando-se de um difratômetro Rigaku MultiFlex. Esses equipamentos estão instalados no Centro de Ciência e Tecnologia de Materiais (CCTM), do Instituto.

E finalmente, como técnica complementar, para se estudar a influência da dose absorvida no catalisador foi utilizada a técnica da espectroscopia de infravermelho por reflexão total atenuada (ATR-FTIR), utilizando-se um Perking-Elmer Spectrum 100, instalado no Centro de Tecnologia das Radiações (CTR), do IPEN-CNEN/SP. 


\subsection{Materiais utilizados e condição inicial}

Os materiais em estudos pertenciam ao ciclo do petróleo, sendo eles catalisadores de Fluid Catalytic Cracking (FCC) e de Hidrocatalytic Cracking (HCC) ambos desativados e regenerados em seu tempo de campanha, e também em seu formato virgem não utilizado no processo de refino.

O catalisador de FCC, mostrado na FIG. 3, possui uma composição básica de óxido de alumínio e dióxido de silício. Sua composição detalhada apresentada na TAB. 1, constitui-se de partículas de tamanhos que variam de $85 \mu \mathrm{m}$ a $140 \mu \mathrm{m}$, apresentando-se na forma de pó fino.

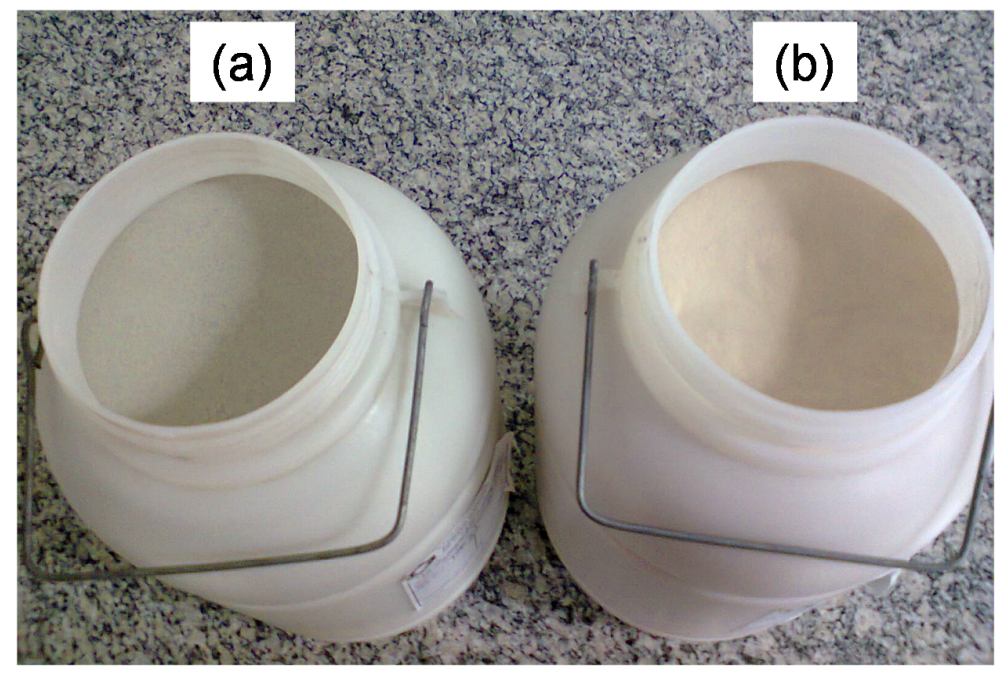

FIGURA 3 - Recipientes contendo catalisadores de FCC: a) desativado e b) virgem. 
TABELA 1 - EDX dos catalisadores virgem e desativado de FCC.

\begin{tabular}{c|c|c}
\hline Óxidos & FCC virgem & FCC desativado \\
\hline$\%$ & & \\
\hline $\mathrm{Al}_{2} \mathrm{O}_{3}$ & $60,9 \pm 0,1$ & $44,8 \pm 0,1$ \\
\hline $\mathrm{SiO}_{2}$ & $35,3 \pm 0,1$ & $47,7 \pm 0,2$ \\
\hline $\mathrm{La}_{2} \mathrm{O}_{3}$ & $2,06 \pm 0,03$ & $2,4 \pm 0,07$ \\
\hline $\mathrm{Fe}_{2} \mathrm{O}_{3}$ & $1,04 \pm 0,02$ & $0,86 \pm 0,01$ \\
\hline $\mathrm{SO}_{3}$ & $0,27 \pm 0,01$ & $0,18 \pm 0,02$ \\
\hline $\mathrm{K}_{2} \mathrm{O}$ & $0,185 \pm 0,004$ & $0,091 \pm 0,010$ \\
\hline $\mathrm{V}_{2} \mathrm{O}_{5}$ & $0,13 \pm 0,01$ & $1,7 \pm 0,3$ \\
\hline $\mathrm{P}_{2} \mathrm{O}_{5}$ & - & $0,58 \pm 0,02$ \\
\hline $\mathrm{CeO}{ }_{2}$ & - & $0,40 \pm 0,03$ \\
\hline$\mu \mathrm{g} \cdot \mathrm{g}-1$ & & \\
\hline $\mathrm{CaO}$ & $235 \pm 22$ & $1900 \pm 200$ \\
\hline $\mathrm{MnO}$ & $143 \pm 22$ & $58 \pm 14$ \\
\hline $\mathrm{ZrO} 2$ & $103 \pm 21$ & $92 \pm 21$ \\
\hline $\mathrm{Ga}_{2} \mathrm{O}_{3}$ & $79 \pm 15$ & $63 \pm 5$ \\
\hline $\mathrm{CuO}$ & $77 \pm 4$ & $82 \pm 4$ \\
\hline $\mathrm{ZnO}$ & $57 \pm 2$ & $122 \pm 7$ \\
\hline $\mathrm{SrO}$ & $39 \pm 2$ & $102 \pm 5$ \\
\hline $\mathrm{NiO}$ & $14 \pm 7$ & $10400 \pm 200$ \\
\hline $\mathrm{Sb} \mathrm{O}_{3}$ & - & $765 \pm 53$ \\
\hline $\mathrm{Rb} \mathrm{O}_{2} \mathrm{O}$ & - & $10 \pm 2$ \\
\hline $\mathrm{PbO}$ & - & $93 \pm 6$ \\
\hline $\mathrm{Número} \mathrm{de} \mathrm{repetições:} 3$ &
\end{tabular}

O catalisador de HCC, apresentado na TAB. 2, possui uma composição básica de óxido de alumínio, óxido de molibdênio e trióxido de enxofre. Diferente do catalisador de FCC, apresenta-se na forma de um extrudado de $4 \mathrm{~mm}$ a $8 \mathrm{~mm}$ de comprimento, por $2 \mathrm{~mm}$ a $5 \mathrm{~mm}$ de diâmetro, tendo como coloração esverdeada para o catalisador virgem e escurecida para o catalisador desativado, mostrados na FIG. 4.

Esse catalisador é utilizado em duas posições diferentes de um mesmo processo, uma no topo da unidade de hidrocraqueamento e outra na base, diferenciando-se, portanto em composição; a da base chamada de leito inferior e a do topo de leito superior.

Toda vidraria utilizada para os experimentos foi lavada seguindo o boletim técnico Aldrich (Aldrich - AL-228). 
TABELA 2 - EDX dos catalisadores de hidrocraqueamento (HCC): virgem e desativados do leito inferior e superior.

\begin{tabular}{c|c|c|c}
\hline Óxidos (\%) & HCC virgem & $\begin{array}{c}\mathrm{HCC} \text { desativado } \\
\text { (leito inferior) }\end{array}$ & $\begin{array}{c}\text { HCC desativado } \\
\text { (leito superior) }\end{array}$ \\
\hline $\mathrm{Al}_{2} \mathrm{O}_{3}$ & $56,234 \pm 0,111$ & $46,098 \pm 0,106$ & $34,212 \pm 0,118$ \\
\hline $\mathrm{As}_{2} \mathrm{O}_{3}$ & - & $0,017 \pm 0,005$ & $0,828 \pm 0,009$ \\
\hline $\mathrm{CaO}$ & $0,084 \pm 0,003$ & $0,119 \pm 0,003$ & $0,339 \pm 0,005$ \\
\hline $\mathrm{Co}_{2} \mathrm{O}_{3}$ & $0,026 \pm 0,003$ & $0,018 \pm 0,003$ & $0,045 \pm 0,005$ \\
\hline $\mathrm{Fe}_{2} \mathrm{O}_{3}$ & $0,02 \pm 0,003$ & $0,233 \pm 0,005$ & $3,649 \pm 0,014$ \\
\hline $\mathrm{MoO}_{3}$ & $23,331 \pm 0,022$ & $19,908 \pm 0,018$ & $13,269 \pm 0,013$ \\
\hline $\mathrm{NiO}$ & $5,367 \pm 0,015$ & $4,349 \pm 0,013$ & $4,74 \pm 0,013$ \\
\hline $\mathrm{P}_{2} \mathrm{O}_{5}$ & $4,063 \pm 0,022$ & $4,241 \pm 0,024$ & $3,29 \pm 0,029$ \\
\hline $\mathrm{SeO}_{2}$ & - & - & $0,006 \pm 0,001$ \\
\hline $\mathrm{SiO}_{2}$ & $0,006 \pm 0,016$ & $0,128 \pm 0,021$ & $8,88 \pm 0,046$ \\
\hline $\mathrm{SO}_{3}$ & $10,865 \pm 0,022$ & $24,855 \pm 0,032$ & $30,152 \pm 0,042$ \\
\hline $\mathrm{V}_{2} \mathrm{O}_{5}$ & $0,001 \pm 0,007$ & $0,027 \pm 0,008$ & $0,546 \pm 0,011$ \\
\hline $\mathrm{ZnO}$ & $0,002 \pm 0,001$ & $0,006 \pm 0,001$ & $0,043 \pm 0,002$ \\
\hline
\end{tabular}

Número de repetições: 3

- Não detectado

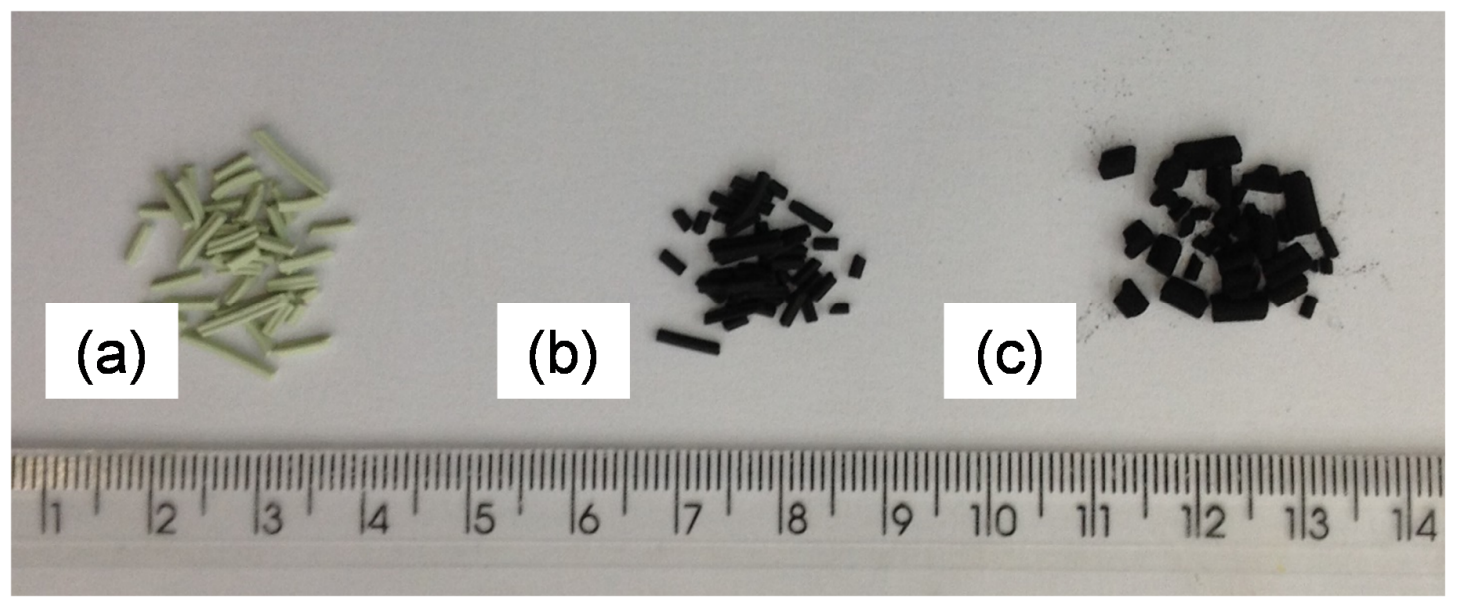

FIGURA 4 - Catalisadores de hidrocraqueamento (HCC): a) virgem; b) desativado do leito inferior; e c) desativado do leito superior. 


\subsubsection{Catalisador de FCC}

Na FIG. 5 é mostrado o diagrama esquemático da rota de trabalho utilizada para a abordagem do estudo do catalisador de FCC.

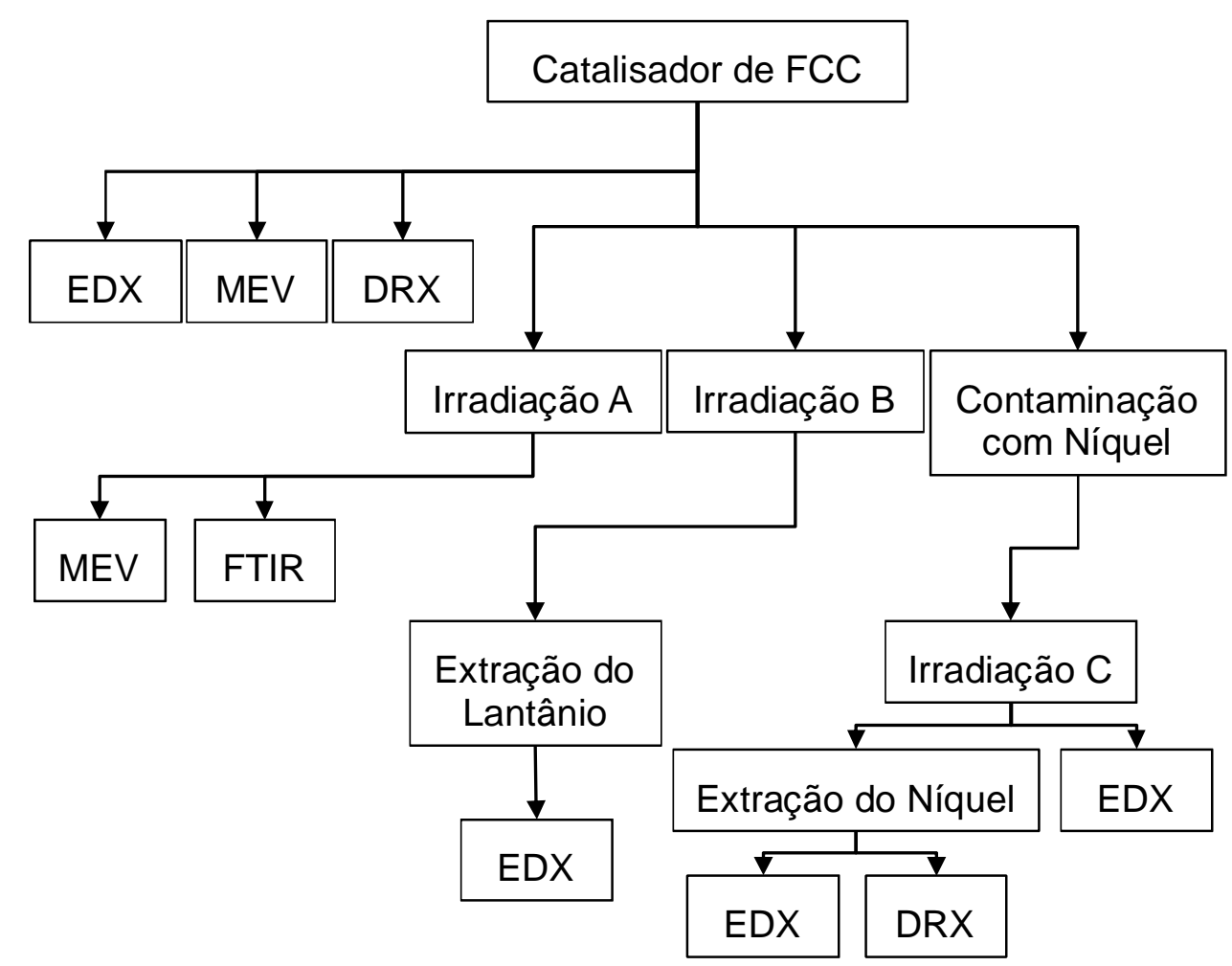

FIGURA 5 - Diagrama esquemático da rota de trabalho para o estudo do catalisador de FCC.

\subsubsection{Análises iniciais}

Os catalisadores de FCC virgem e desativado, foram submetidos às análises de fluorescência de raios $X$ por energia dispersiva (EDX) para uma caracterização inicial e identificação das suas composições, conforme apresentado na TAB 1.

Nota-se que a concentração de lantânio $\left(\mathrm{La}_{2} \mathrm{O}_{3}\right)$ no catalisador de FCC desativado está em cerca de 2,4\% da composição total. Os catalisadores de FCC possuem em sua composição óxidos de terras-raras, na sua maioria lantânio, e pequenas quantias de cério, praseodímio e neodímio (Yu e Chen, 1995). O íon de terra-rara ajuda a estabilizar a estrutura zeolítica de catalisadores de FCC. 
Inclusive, essa aplicação consome cerca de 50\% da produção mundial de lantânio. Não obstante, há muito pouco interesse na reciclagem de terras-raras a partir de catalisadores desativados de FCC (Binnemans et al., 2013) sendo a maioria dos estudos voltados à recuperação de terras-raras por lixiviação com soluções ácidas (He e Meng, 2011; Vierheilig, 2012).

A composição inicial do catalisador é predominantemente óxido de alumínio e dióxido de silício. Quando o catalisador atinge o final de sua vida útil é considerado desativado e há uma mudança na porcentagem de dióxido de silício que aumenta significativamente, assim como nos níveis de óxidos de níquel, considerado um dos contaminantes mais significativos para a desativação irreversível do catalisador.

O elemento níquel foi observado em um trabalho de Myrstad intitulado Effect of nickel and vanadium on sulphur reduction of FCC naphtha (Myrstad et al., 2000) e também revisto por Cerqueira em Deactivation of FCC catalysts (Cerqueira et al., 2008). Além de ser considerado um contaminante para o catalisador, o níquel é um possível carcinógeno humano como descrito na ficha de informação toxicológica da CETESB (Companhia Ambiental do Estado de São Paulo, 2014) e, portanto, deve ser descartado de forma correta.

Para se ter um melhor entendimento sobre a forma do catalisador, assim como seu tamanho médio de partícula, analisou-se o catalisador ao microscópio eletrônico de varredura. Sua forma e tamanho serão usados como base para um melhor entendimento da ação da radiação ionizante no catalisador. Para se compreender a forma do catalisador, mostrada na FIG. 6, alguns pontos da amostra foram analisados e extraídas imagens; já para a análise do tamanho médio de partícula, apresentada na TAB. 3, várias partículas foram selecionadas dentro do conjunto e realizada a média dos diâmetros das mesmas.

Apesar da forma adotada ter suas limitações, conforme ressalva Papini (Papini, 2003), para se obter um valor confiável o número de partículas deve ser estatisticamente representativo, assim como uma amostra que represente o lote, e que esteja bem dispersa. No ensaio em questão a microscopia eletrônica de 
varredura $(\mathrm{MEV})$ foi uma técnica altamente eficaz em não selecionar aglomerados para se realizar as medições das partículas individuais.

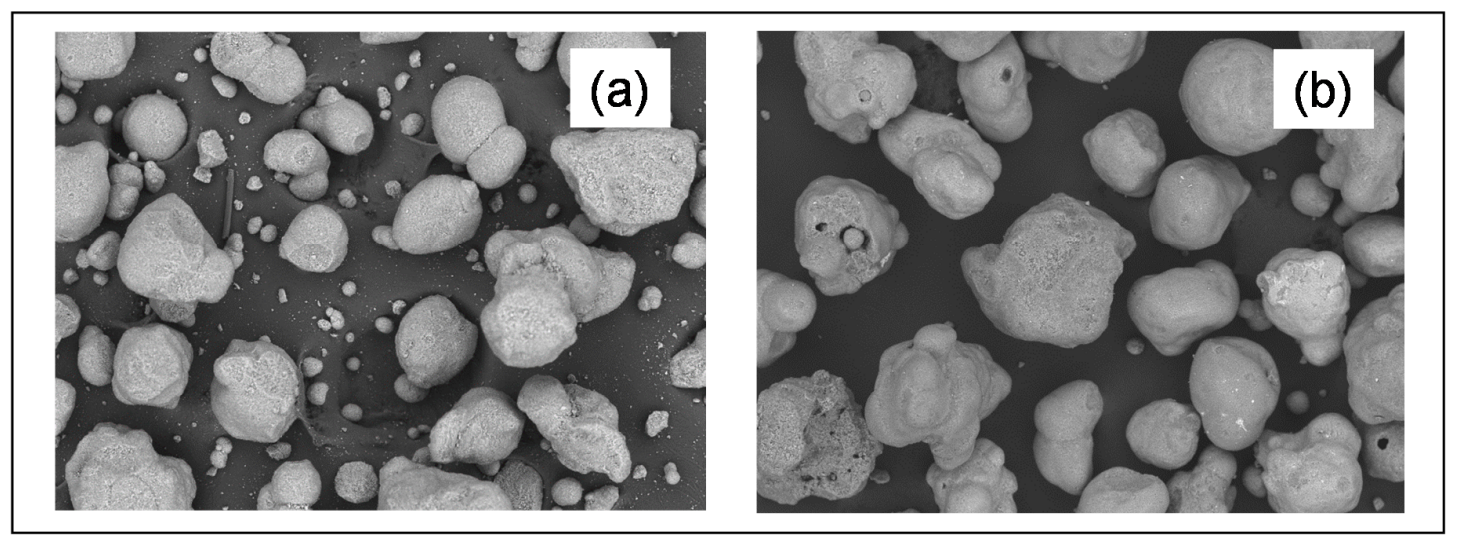

FIGURA 6 - Microscopia Eletrônica de Varredura (x250) dos catalisadores de FCC: a) virgem e b) desativado.

TABELA 3 - Tamanho médio das partículas do catalisador de FCC.

\begin{tabular}{c|c}
\hline Catalisador de FCC & Média das partículas $(\mu \mathrm{m})$ \\
\hline Virgem & 125 \\
\hline Desativado & 92,5 \\
\hline
\end{tabular}

Por meio da microscopia eletrônica de varredura (MEV) verificou-se que dentre os catalisadores, o de maior diâmetro é o catalisador virgem. Isso se explica pelo fato de não terem sidos expostos às condições de catálise. É possível verificar também que possuem um formato esferoidal. O catalisador desativado, por outro lado, apesar de apresentar um formato similar ao catalisador virgem possui em média menor diâmetro de largura, muitas vezes com rupturas e até mesmo furos em sua estrutura. Acredita-se que isso ocorra em função do catalisador, por diversos ciclos, ser exposto a temperatura e pressão elevadas. 
Por fim, fez-se a difração de raios $X$ do catalisador de FCC para se compreender a estrutura cristalina inicial e obtiveram-se os seguintes difratogramas mostrados nas FIG. 7 e 8.

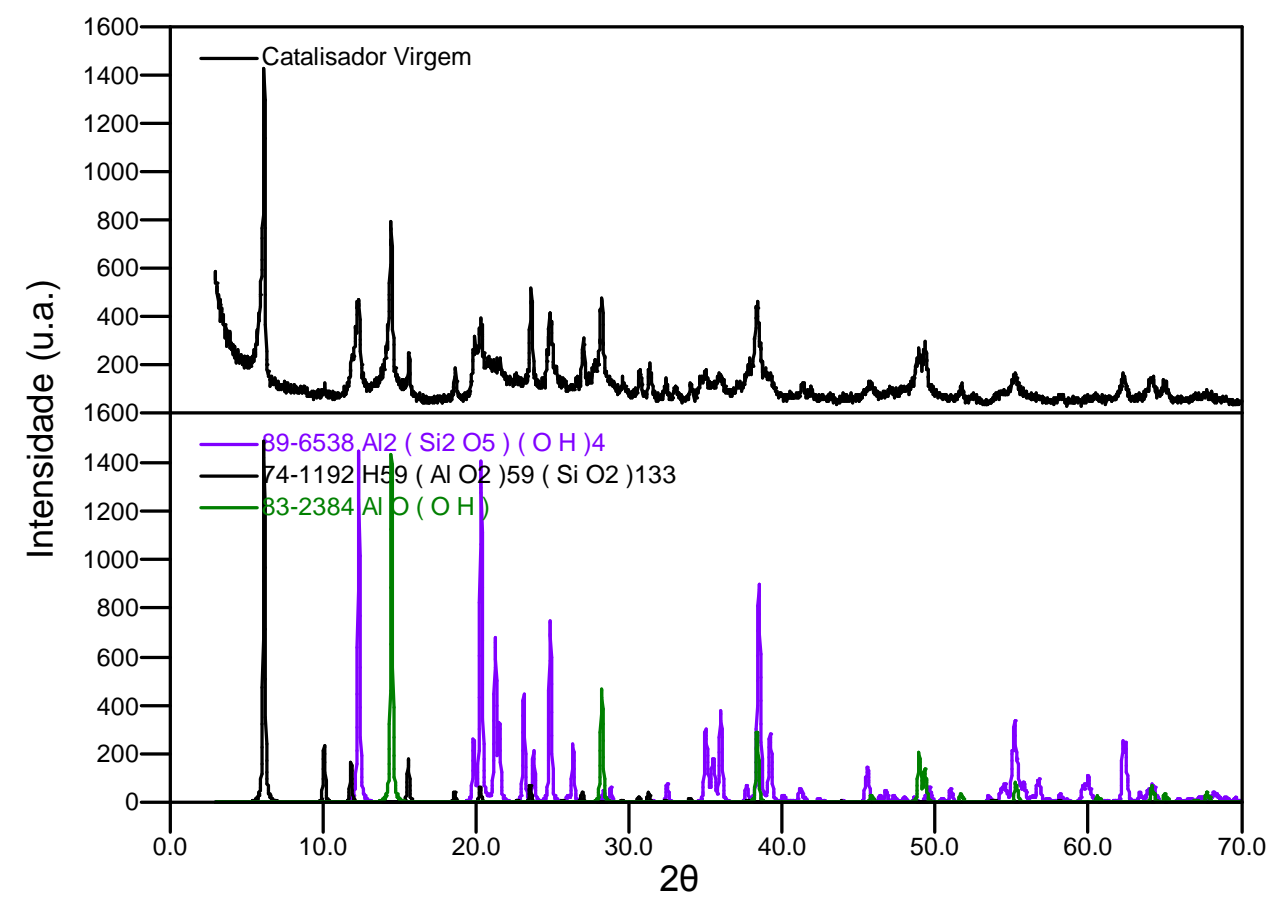

FIGURA 7 - Difratograma de Raios X do catalisador de FCC virgem. 


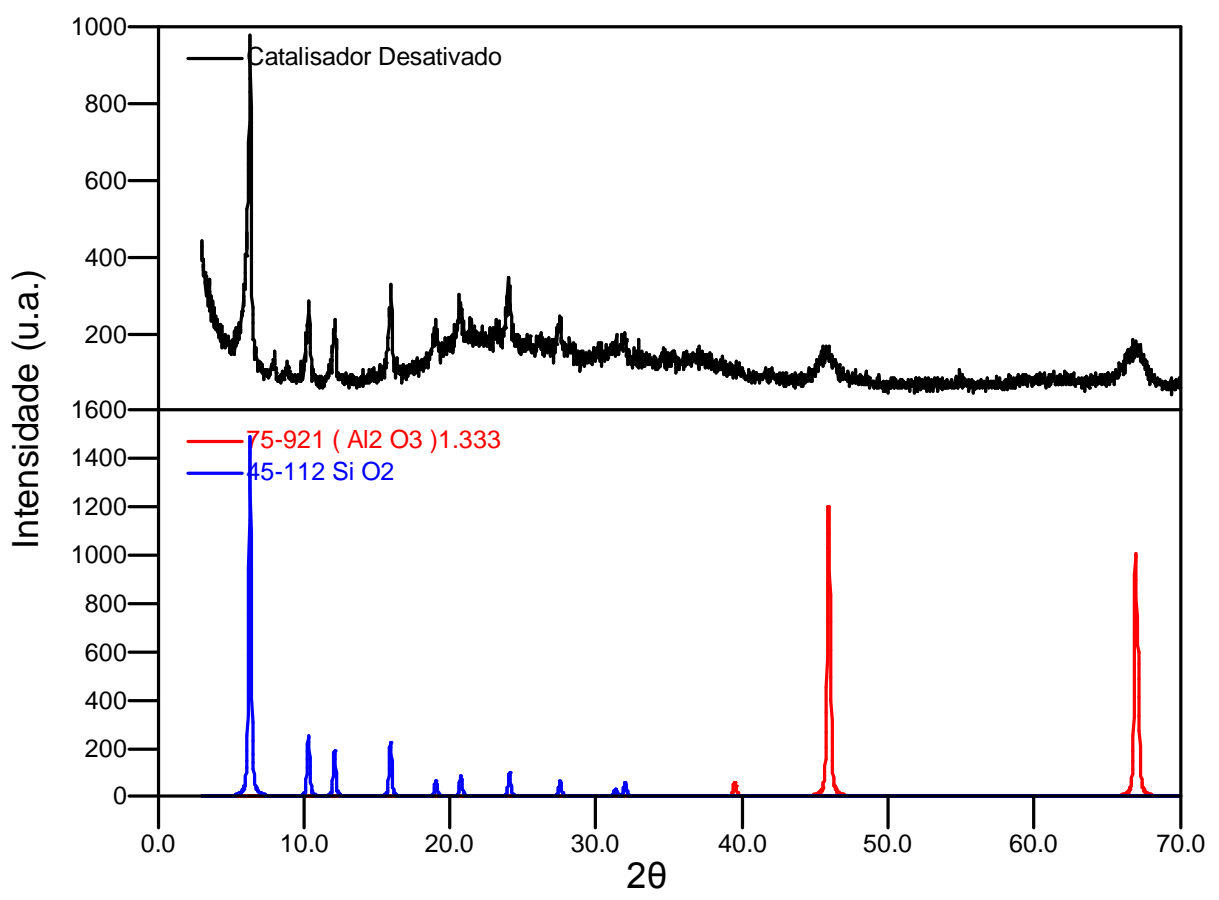

FIGURA 8 - Difratograma de Raios X do catalisador de FCC desativado.

Inicialmente tem-se o catalisador virgem com as fases cristalinas de caolinita (roxo), h-faujasita (preto) e boemita (verde) bem características. Após o uso constante desse catalisador e por diversas vezes passar pelo regenerador (altas temperatura e pressão) acaba por ser consumido. Cristalograficamente essas fases iniciais transformam-se, respectivamente, em uma fase amorfa contendo silício e alumínio representado pela "barriga" (desvio da linha base) do backgound, dióxido de silício (azul) e alumina gama (vermelho).

\subsubsection{Preparo das amostras}

O preparo dos catalisadores de FCC resume-se aos processamentos por radiação, assim como a contaminação do catalisador virgem com níquel. As condições para cada preparo são detalhadas nos itens: Irradiação A a C. 
Irradiação A - As amostras de catalisador de FCC virgem e desativado foram separadas em quatro lotes de $10 \mathrm{~g}$ e acondicionadas em frascos de vidro com tampa de borracha, e submetidas a radiação gama em temperatura ambiente utilizando-se do irradiador multipropósito de cobalto-60, do CTR localizado no IPEN, até se atingirem doses absorvidas de 20 kGy, 50 kGy, 100 kGy e 150 kGy, numa taxa de dose de 6,5 kGy/h, aproximadamente.

O estudo da influência da radiação gama na superfície dos catalisadores iniciou na década de 90 (Youssef et al., 1990). Mas, estudos indicam que catalisadores de sílica-alumina sofrem redução da área superficial, aumento do tamanho do poro quando tratados com raios gama (Youssef et al., 1992). Ainda que esse não seja o foco do presente trabalho o que demandariam outros estudos voltados nesse aspecto.

Irradiação B - Amostras de catalisador de FCC desativado foram submetidas a radiação utilizando-se de um acelerador industrial de elétrons, Dynamitron DC1500/25/04, modelo JOB 188, do Centro de Tecnologia das Radiações, localizado no IPEN-CNEN/SP. Iniciou-se a irradiação em temperatura ambiente e o porta-amostra foi posicionado de forma estática em baixo do feixe de elétrons, com energia utilizada de 1,3 MeV, corrente do feixe de 3,5 mA, e taxa de dose de $25,3 \mathrm{kGy} / \mathrm{s}$. O porta-amostra ficou exposto a radiação por 20 minutos somando uma dose absorvida final de 30,36 MGy e uma temperatura máxima de $558^{\circ} \mathrm{C}$. Foram irradiadas amostras de $9,78 \mathrm{~g}$ cada, massa essa obtida ao completar cerca de $2 \mathrm{~mm}$ em expessura da cavidade do porta-amostra, confeccionada em aço inoxidável AISI 304.

Seguido da irradiação, para a extração de lantânio do catalisador desativado foi utilizado o método de lixiviação com ácidos (He e Meng, 2011) e estudado comparativamente catalisadores desativado e desativado irradiado, sendo esse o principal foco no estudo do catalisador de FCC. Esses ensaios foram feitos apenas com os catalisadores desativados, considerados para a indústria do 
petróleo como resíduo sólido. Foi estabelecido o valor percentual do lantânio em 2,4\% de $\mathrm{La}_{2} \mathrm{O}_{3}$ para futuros cálculos, conforme apresentado na TAB. 1.

Tal método consiste na lixiviação com ácidos. Utilizo-se ácido clorídrico $(\mathrm{HCl})$ a uma concentração de $3,5 \mathrm{~mol} / \mathrm{L}$ e um volume de $500 \mathrm{~mL}$, e $9,78 \mathrm{~g}$ de catalisador de FCC. Após a filtração do catalisador o mesmo foi levado a estufa e seco a $130^{\circ} \mathrm{C}$, por 30 minutos.

Irradiação C - Um lote de catalisador de FCC virgem foi contaminado com níquel e irradiado, utilizando-se do mesmo acelerador industrial de elétrons da Irradiação B. Entretanto, utilizou-se um sistema de passagem de bandeja por baixo do feixe de elétrons, a uma velocidade de $6,72 \mathrm{~m} / \mathrm{min}$, energia de 0,904 MeV, corrente do feixe de 4,18 mA e uma taxa de dose de 22,39 kGy/s, até atingir uma dose absorvida de 20 kGy e 150 kGy. Utilizaram-se placas de petri com 0,20 g de amostra cada.

Tendo o níquel como elemento contaminante que se deposita na superfície do catalisador, envenenando-o, o que prejudica sua seletividade, e conseqüentemente observam-se os seguintes efeitos: aumento na produção de coque e diminuição na produção de gasolina, dentre outros. (Upson, 1981; Decroocq, 1984; Wojciechowski e Corma, 1986; Engelhard Coporation, 1994; Wilson, 1997).

Contaminação do catalisador virgem com níquel - Simulou-se uma contaminação a 5000 ppm em níquel, referente a metade do encontrado no catalisador desativado, aproximadamente, pelo método de Mitchell (Mitchell, 1980), o qual baseia-se na impregnação incipiente (incipiente wetness impregnation) do contaminante níquel, seguido de tratamentos térmicos a $500^{\circ} \mathrm{C}$ por 1 hora e $750^{\circ} \mathrm{C}$ por 2 horas.

Após a contaminação, o catalisador foi irradiado conforme descrito na Irradiação $\mathbf{C}$ e, em sequência, realizado um tratamento com diclorometano para realizar a extração do níquel encontrando na superfície do catalisador. Esse método 
(Guisnet et al., 2009) é o primeiro passo para a eliminação do coque solúvel depositado na superfície do catalisador e por isso escolhido como ensaio na extração do níquel, uma vez que o mesmo se aloja na superfície do catalisador. O método consiste na extração sob refluxo com diclorometano. O sistema é composto por um balão de fundo redondo acoplado a um condensador allihn, também chamado de condensador de refluxo e aquecido sobre manta de aquecimento. Nesse sistema utilizaram-se pérolas de vidro para se evitar a ebulição violenta.

Dentre os ensaios realizados com 0,2 g de catalisador de FCC contaminado, observou-se que o processo ideal demandaria cerca de $25 \mathrm{~g}$ de diclorometano, em função das dimensões da vidraria e o escape de diclorometano do sistema decorrente da sua alta volatilidade. Por fim, realizaram-se seis ensaios dividos em três categorias:

a) Catalisador contaminado e refluxado com diclorometano por 1 hora;

b) Catalisador contaminado e refluxado com diclorometano por 3 horas e 40 minutos; e

c) Catalisador contaminado, irradiado com 20kGy e refluxado com diclorometano por 1 hora.

Para cada categoria foram realizados dois ensaios, sendo que os ensaios de uma mesma categoria foram unidos em uma mesma amostra final e homogeneizada para maior reprodutibilidade.

\subsubsection{Resultados e discussão}

Irradiação A - Como estudo inicial realizou-se a microscopia (MEV) dos catalisadores irradiados, para se verificar alguma mudança no aspecto ou tamanho médio de partículas. Na FIG. 9 são mostradas as micrografias dos catalisadores irradiados por raios gama, em comparação com os não irradiados. 


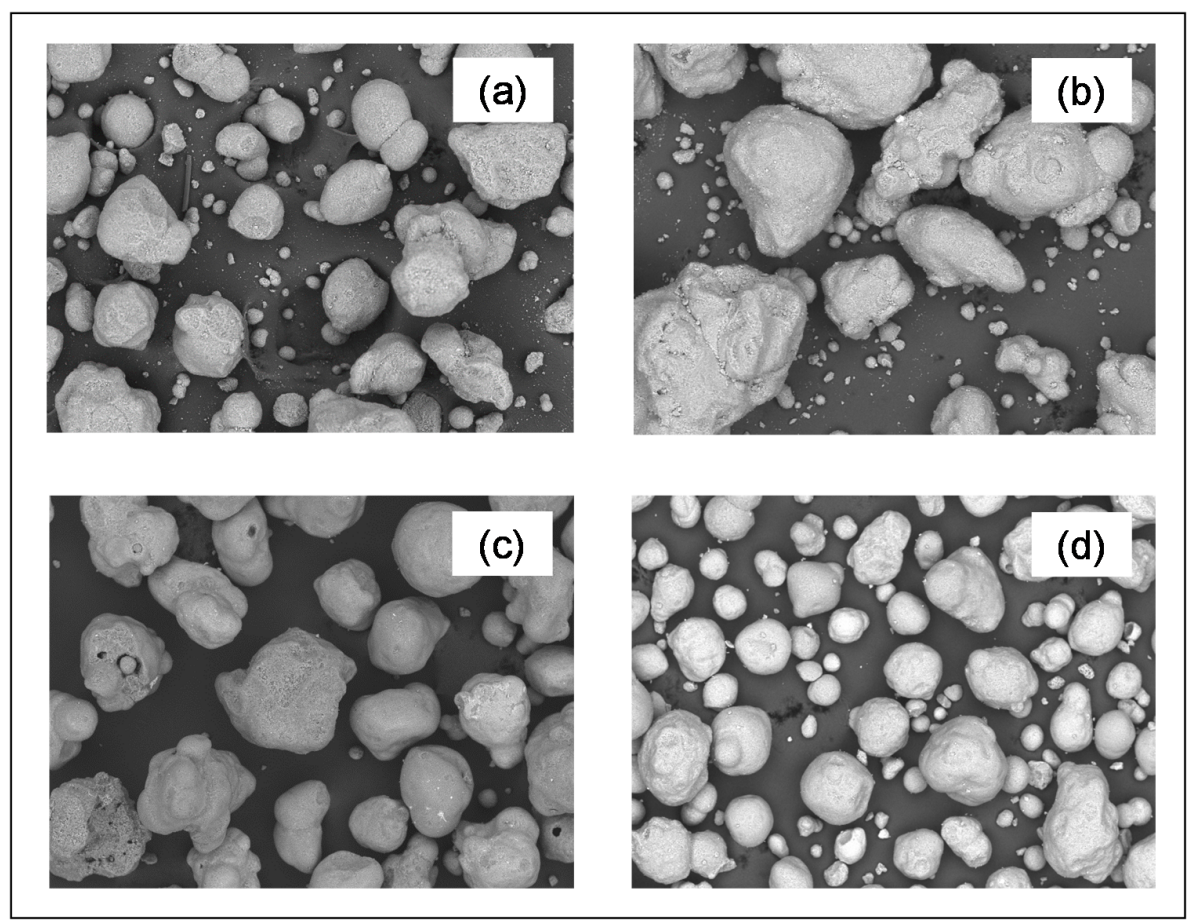

FIGURA 9 - Microscopia Eletrônica de Varredura (x250) dos catalisadores de FCC: a) virgem; b) virgem e irradiado a $20 \mathrm{kGy}$; c) desativado; e d) desativado e irradiado a 20kGy por raios gama.

Pela micrografia (FIG.9) é possível verificar-se algumas mudanças sutis na aparência do catalisador após irradiação por raios gama, tais como, aumento do diâmetro médio das partículas do catalisador virgem e irradiado a 20 kGy.

Os catalisadores de FCC foram analisados sob a ótica da espectroscopia de infravermelho por transformada de Fourier (FTIR), para compreender a influêcia do processo de irradiação nos catalisadores virgem e desativado, obtendo-se os espectros mostrados nas FIG. 10 e 11. 


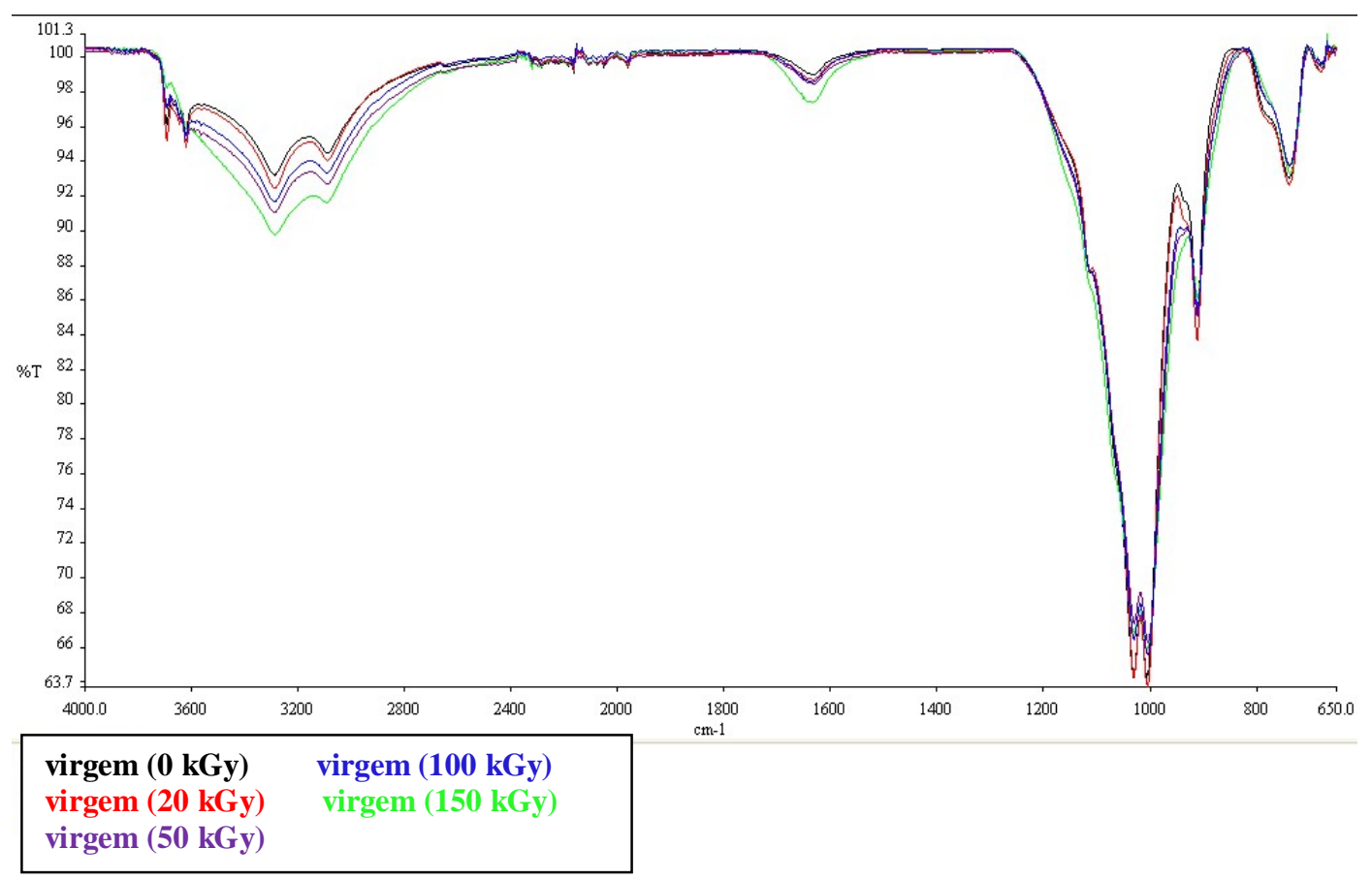

FIGURA 10 - Espectros de infravermelho para os catalisadores de FCC virgem e virgem irradiado (raios gama), nas doses absorvidas de $20 \mathrm{kGy}$, 50 kGy, 100 kGy e 150 kGy.

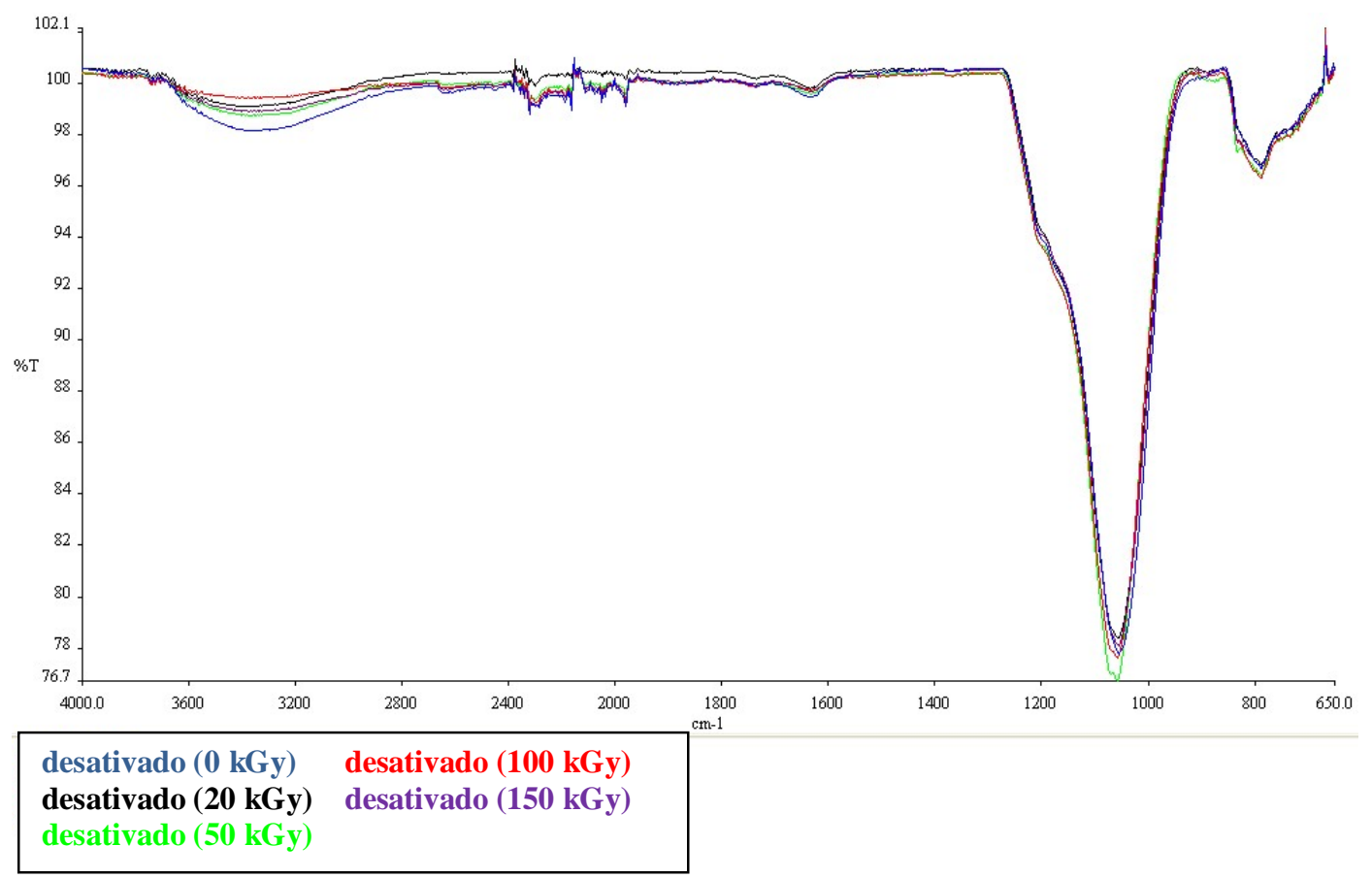

FIGURA 11 - Espectros de infravermelho para os catalisadores de FCC desativado e desativado irradiado (raios gama), nas doses absorvidas de 20 kGy, 50 kGy, 100 kGy e 150 kGy. 
Essa técnica foi utilizada para se correlacionar os espectros e estudar a influência da radiação gama no catalisador. Em primeiro momento nota-se que a irradiação não foi capaz de alterar a molécula do catalisador e nenhuma mudança foi percebida no que diz respeito a energia vibracional da estrutura molecular. Logo, não há diferença significativa entre o catalisador irradiado com raios gama (20 kGy, 50 kGy, 100 kGy e 150 kGy) e o não irradiado. As informações provenientes do ATR-FTIR são compatíveis com aquelas obtidas pela difração de raios $\mathrm{X}$, em concordância com os dados obtidos pela fluorescência de raios $X$, no que diz respeito as suas fases características. Os espectros de infravemerlho mostradas nas FIG. 12, 13 e 14 evidenciam os picos característicos dos elementos presente no catalisador virgem de FCC concordante com as análises por DRX e EDX.

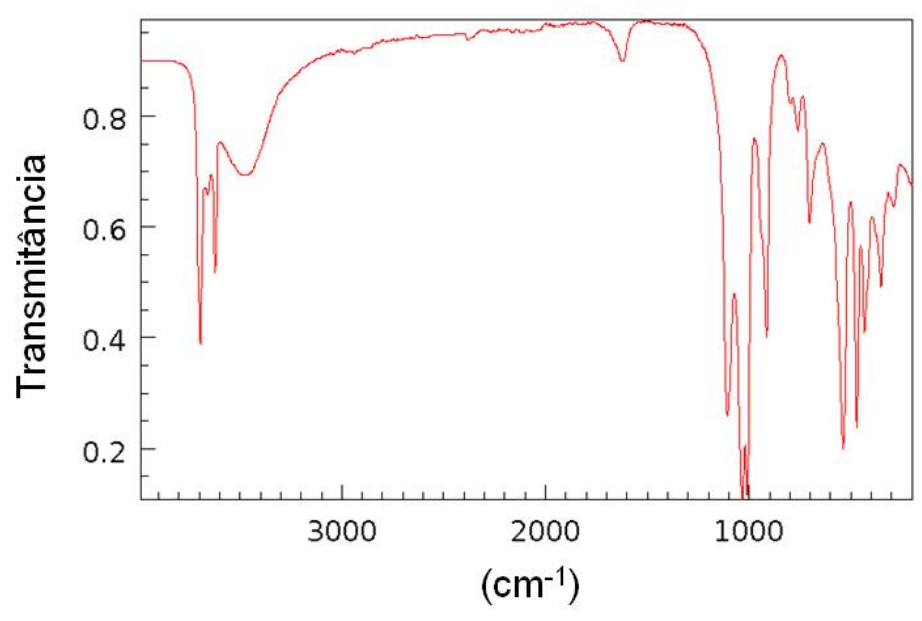

Fonte: NIST Chemistry WebBook.

FIGURA 12 - Espectro de infravermelho do silicato de alumínio. 


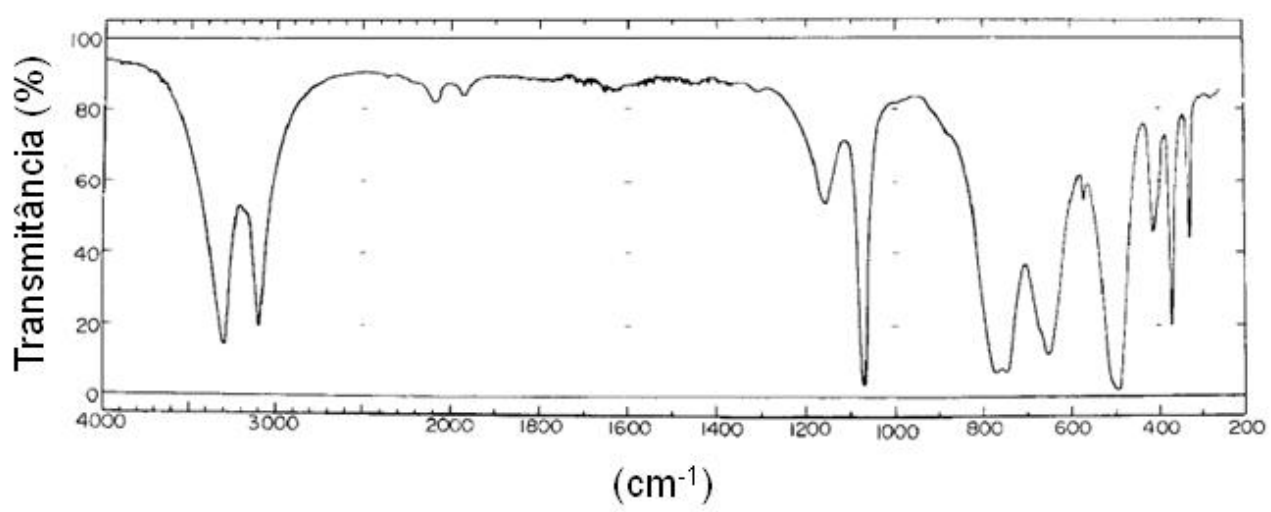

Fonte: Keresztury et al., 1980.

FIGURA 13 - Espectro de infravermelho da Bohemita.

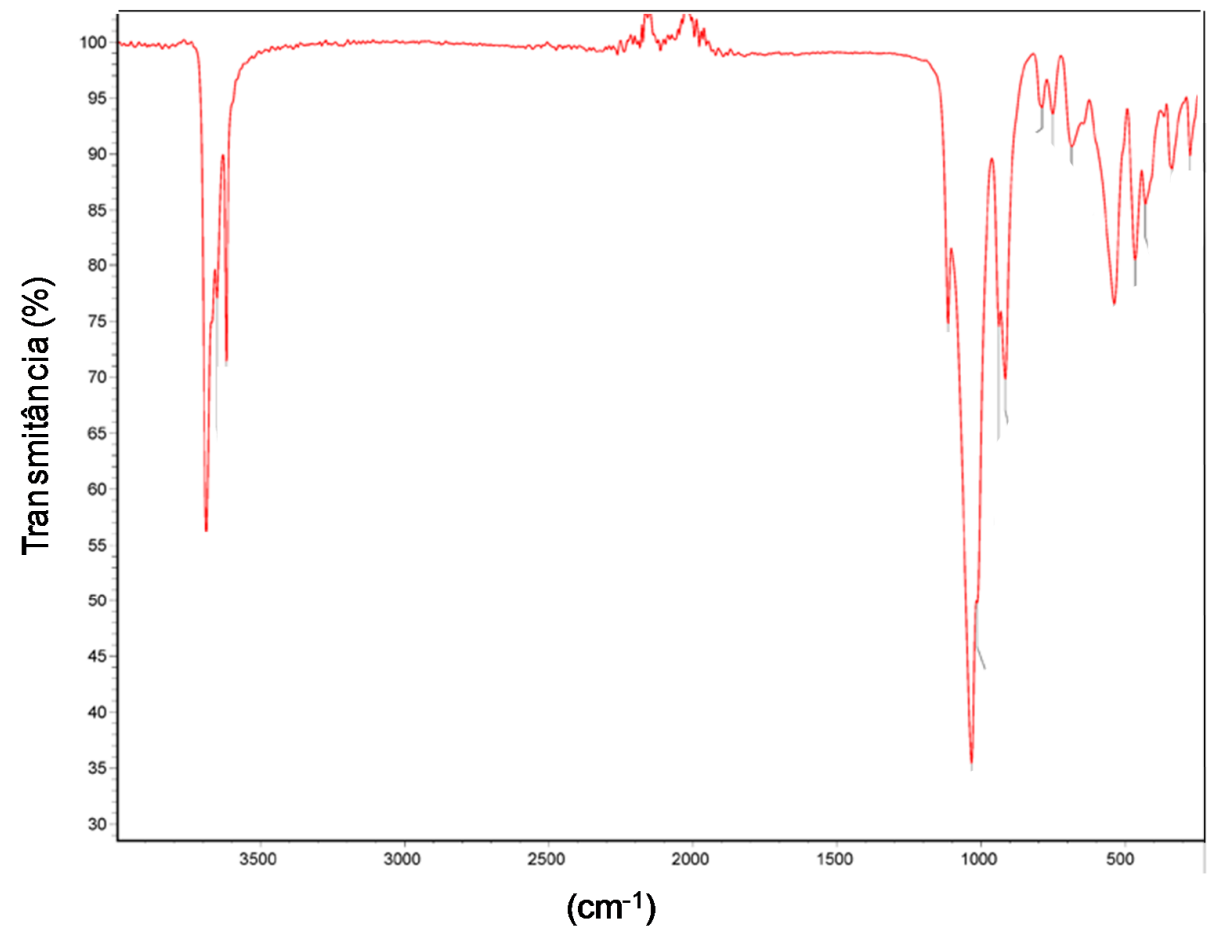

Fonte: IR-Spectra, Institute of Chemistry, University of Tartu, Estonia.

FIGURA 14 - Espectro de infravermelho da caulinita. 
Irradiação B - Os estudos envolvendo a extração de terras-raras do catalisador desativado de FCC por radiação gama, com doses absorvidas de 20 kGy a 150 kGy, não representaram contribuições significativas. Por esse motivo, empregou-se no tratamento dos catalisadores de FCC uma dose absorvida superior a empregada nos outros estudos (30,36 MGy com elétrons de 1,3 MeV e temperatura máxima de $558{ }^{\circ} \mathrm{C}$ ), utilizada também no processamento do catalisador de HCC.

Os dois lotes de catalisadores de FCC, desativado e desativado irradiado, foram processados pelo método de He e Meng (2011), para se avaliar a colaboração da irradiação por feixe de elétrons no processo de extração de terras-raras, nesse caso, do lantânio.

Portanto, para se estudar o rendimento da extração, o catalisador que passou pelo processo de extração foi submetido a uma última análise, pela técnica de EDX, conforme apresentada na TAB. 4.

TABELA 4 - EDX dos catalisadores de FCC desativado e desativado irradiado por feixe de elétrons (30,36 MGy), após tratamento químico.

\begin{tabular}{c|c|c}
\hline Óxidos (\%) & FCC desativado & $\begin{array}{c}\text { FCC desativado } \\
\text { e irradiado }\end{array}$ \\
\hline $\mathrm{SiO}_{2}$ & $57,834 \pm 0,075$ & $57,924 \pm 0,074$ \\
\hline $\mathrm{Al}_{2} \mathrm{O}_{3}$ & $37,694 \pm 0,084$ & $37,994 \pm 0,083$ \\
\hline $\mathrm{NiO}$ & $1,246 \pm 0,003$ & $1,092 \pm 0,003$ \\
\hline $\mathrm{V}_{2} \mathrm{O}_{5}$ & $1,027 \pm 0,007$ & $0,961 \pm 0,007$ \\
\hline $\mathrm{Fe}_{2} \mathrm{O}_{3}$ & $0,702 \pm 0,003$ & $0,647 \pm 0,003$ \\
\hline $\mathrm{La}_{2} \mathrm{O}_{3}$ & $0,564 \pm 0,007$ & $0,531 \pm 0,007$ \\
\hline $\mathrm{TiO}_{2}$ & $0,407 \pm 0,006$ & $0,315 \pm 0,006$ \\
\hline $\mathrm{P}_{2} \mathrm{O}_{5}$ & $0,157 \pm 0,009$ & $0,214 \pm 0,009$ \\
\hline $\mathrm{SO}_{3}$ & $0,143 \pm 0,004$ & $0,113 \pm 0,004$ \\
\hline $\mathrm{CaO}_{\mathrm{Co}} \mathrm{O}_{3}$ & $0,071 \pm 0,002$ & $0,068 \pm 0,002$ \\
\hline $\mathrm{Sb}_{2} \mathrm{O}_{3}$ & $0,067 \pm 0,001$ & $0,055 \pm 0,001$ \\
\hline $\mathrm{ZnO}_{\mathrm{ZrO}}$ & $0,04 \pm 0,001$ & $0,048 \pm 0,001$ \\
\hline $\mathrm{Ga}_{2} \mathrm{O}_{3}$ & $0,023 \pm 0,000$ & $0,02 \pm 0,000$ \\
\hline $\mathrm{SrO}$ & $0,012 \pm 0,000$ & $0,008 \pm 0,000$ \\
\hline
\end{tabular}


Após realizar o EDX nos catalisadores, assegurou-se que ambos os catalisadores (irradiado e não irradiado) possuiam uma quantia percentual final de lantânio equivalente. Contudo, esses valores absolutos não foram utilizados no cálculo de lantânio extraído, pois houve uma mudança percentual em todos os elementos se comparado com as porcentagens do catalisador desativado, cujos valores são apresentados na TAB. 1.

Assumiu-se o dióxido de silício $\left(\mathrm{SiO}_{2}\right)$ como elemento padrão de análise, uma vez que o mesmo possui uma temperatura de fusão de $1610^{\circ} \mathrm{C}$, e de ebulição de $2230^{\circ} \mathrm{C}$ (BBC - Science, Rocks and minerals), o que garante sua permanência em todos os ensaios, sabendo-se que a temperatura máxima atingida nas irradiações por feixe de elétrons foi de $558^{\circ} \mathrm{C}$.

Portanto, para efetuar o balanço geral de massas, é necessário o uso de um elemento padrão que não saiu da amostra. Efetuando-se a razão do elemento a ser estudado, lantânio no caso, em relação ao elemento padrão, conforme a Equação 1, é possível afirmar com mais segurança qual o percentual de lantânio na amostra, e por consequência, o percentual de sua extração. Os valores dos $\left(\mathrm{La}_{2} \mathrm{O}_{3}\right)_{\text {antes }}$ e $\left(\mathrm{SiO}_{2}\right)$ antes no catalisador de $\mathrm{FCC}$ desativado são, respectivamente, iguais a 2,4\% e 47,7\%, extraídos da TAB. 1 .

$$
\text { Extração de lantânio }(\%)=\frac{\left(\frac{L a 2 O 3}{S i O 2}\right) \text { depois }}{\left(\frac{L a 2 O 3}{S i O 2}\right) \text { antes }} \times 100
$$

Feito esse estudo (Equação 1), considerando-se os resultados apresentados na TAB.4, houve uma porcentagem de eliminação de lantânio $\left(\mathrm{La}_{2} \mathrm{O}_{3}\right)$ de $80,62 \%$ para o catalisador desativado, e de 81,78\% para o catalisador desativado e irradiado por feixe de elétrons (30,36 MGy a $\left.558{ }^{\circ} \mathrm{C}\right)$. Portanto, fica evidente que a participação da radiação na extração de lantânio do catalisador de FCC, é insignificante nas condições estudadas. 


\section{Contaminação do catalisador virgem com níquel e} irradiação C - Nesse estudo foi separado uma amostra do catalisador de FCC virgem e seguindo o método de Mitchell contaminou-se o catalisador com 5000 ppm de níquel simulando um catalisador de meia-vida. Após a contaminação os catalisadores foram irradiados por feixe de elétrons conforme descrito no item 4.2.1.2. Preparo das amostras - Irradiação C.

Para um estudo incial, realizou-se a análise por espectroscopia de fluorescência de raios X (EDX), cujos resultados são apresentados na TAB. 5, para compreender se a metodologia aplicada alteraria de alguma forma a composição do catalisador, além da mudança na concentração de níquel.

Após se obter a referência da composição química do material, seguiu-se pelo método de Guisnet (Guisnet et al., 2009) para a eliminação do níquel presente na superfície do catalisador, sendo que após o tratamento, repetiu-se a análise de EDX para comparação dos valores apresentados na TAB. 6 .

TABELA 5 - EDX do catalisador de FCC contaminado com níquel e irradiado com feixe de elétrons, nas doses absorvidas de 20 kGy e 150 kGy.

\begin{tabular}{c|c|c}
\hline Óxidos & $\begin{array}{c}\text { FCC contaminado e } \\
\text { irradiado (20 kGy) }\end{array}$ & $\begin{array}{c}\text { FCC contaminado e } \\
\text { irradiado (150 kGy) }\end{array}$ \\
\hline$\%$ & & \\
\hline $\mathrm{Al}_{2} \mathrm{O}_{3}$ & $60,6 \pm 0,3$ & $60,8 \pm 0,3$ \\
\hline $\mathrm{SiO}_{2}$ & $38,5 \pm 0,2$ & $35,0 \pm 0,2$ \\
\hline $\mathrm{La}_{2} \mathrm{O}_{3}$ & $1,43 \pm 0,03$ & $1,48 \pm 0,03$ \\
\hline $\mathrm{Fe}_{2} \mathrm{O}_{3}$ & $0,95 \pm 0,01$ & $0,95 \pm 0,02$ \\
\hline $\mathrm{TiO}_{2}$ & $0,87 \pm 0,03$ & $0,79 \pm 0,03$ \\
\hline $\mathrm{NiO}^{2}$ & $0,54 \pm 0,006$ & $0,52 \pm 0,006$ \\
\hline $\mathrm{SO}_{3}$ & $0,26 \pm 0,02$ & $0,34 \pm 0,02$ \\
\hline $\mathrm{K}_{2} \mathrm{O}$ & $0,14 \pm 0,01$ & $0,13 \pm 0,01$ \\
\hline$\mu \mathrm{g}_{9} \mathbf{9}$ & & $364 \pm 70$ \\
\hline $\mathrm{CaO}_{\mathrm{ZnO}}$ & $209 \pm 50$ & $209 \pm 18$ \\
\hline $\mathrm{Ga}_{2} \mathrm{O}_{3}$ & $75 \pm 10$ & $78 \pm 15$ \\
\hline $\mathrm{ZrO} 2$ & $133 \pm 8$ & $100 \pm 10$ \\
\hline $\mathrm{SrO}$ & $39 \pm 6$ & $33 \pm 9$ \\
\hline
\end{tabular}


TABELA 6 - EDX dos catalisadores de FCC contaminados com níquel, refluxados (60 min e $220 \mathrm{~min}$ ) e irradiado com doses de 20 kGy por feixe de elétrons.

\begin{tabular}{c|c|c|c}
\hline Óxidos & $\begin{array}{c}\mathrm{FCC} \\
\text { contaminado } \\
\text { e refluxado } \\
(60 \mathrm{~min})\end{array}$ & $\begin{array}{c}\text { FCC contaminado, } \\
\text { irradiado }(20 \mathrm{kGy}) \mathrm{e} \\
\text { refluxado }(60 \mathrm{~min})\end{array}$ & $\begin{array}{c}\mathrm{FCC} \\
\text { contaminado } \\
\text { e refluxado } \\
(220 \mathrm{~min})\end{array}$ \\
\hline$\%$ & & & \\
\hline $\mathrm{Al}_{2} \mathrm{O}_{3}$ & $61,1 \pm 0,3$ & $60,9 \pm 0,1$ & $60,9 \pm 0,3$ \\
\hline $\mathrm{SiO}_{2}$ & $34,8 \pm 0,2$ & $34,8 \pm 0,1$ & $35,1 \pm 0,1$ \\
\hline $\mathrm{La}_{2} \mathrm{O}_{3}$ & $1,41 \pm 0,03$ & $1,45 \pm 0,03$ & $1,37 \pm 0,03$ \\
\hline $\mathrm{Fe}_{2} \mathrm{O}_{3}$ & $0,93 \pm 0,01$ & $0,94 \pm 0,01$ & $0,884 \pm 0,01$ \\
\hline $\mathrm{TiO}_{2}$ & $0,86 \pm 0,03$ & $0,87 \pm 0,02$ & $0,83 \pm 0,02$ \\
\hline $\mathrm{NiO}$ & $0,511 \pm 0,006$ & $0,521 \pm 0,006$ & $0,492 \pm 0,006$ \\
\hline $\mathrm{SO}_{3}$ & $0,264 \pm 0,02$ & $0,31 \pm 0,01$ & $0,32 \pm 0,01$ \\
\hline $\mathrm{K}_{2} \mathrm{O}$ & $0,14 \pm 0,01$ & $0,197 \pm 0,009$ & $0,15 \pm 0,01$ \\
\hline $\boldsymbol{\mu g} \cdot \mathbf{g}-1$ & & & \\
\hline $\mathrm{CaO}$ & $240 \pm 50$ & $320 \pm 60$ & $378 \pm 60$ \\
\hline $\mathrm{ZnO}$ & $73 \pm 10$ & $100 \pm 10$ & $98 \pm 8$ \\
\hline $\mathrm{Ga}_{2} \mathrm{O}_{3}$ & $73 \pm 10$ & $70 \pm 4$ & $76 \pm 10$ \\
\hline $\mathrm{ZrO}$ & $104 \pm 7$ & $120 \pm 6$ & $70 \pm 5$ \\
\hline $\mathrm{SrO}$ & $31 \pm 6$ & $10 \pm 1$ & $26 \pm 6$ \\
\hline Numero de repeticões: 3 & &
\end{tabular}

Na TAB. 5 é possível verificar que a contaminação com níquel (NiO) ocorreu conforme o esperado, e comparativamente ao catalisador de FCC virgem (14 \pm 7 ppm ou $0,0014 \% \pm 0,0007 \%$ ), não houve mudanças significativas em sua composição química (TAB. 1). Essa primeira interpretação é válida para mostrar que além do aumento do níquel o processo de contaminação não alterou a composição do catalisador de FCC, assim como diferentes doses de radiação com feixe de elétrons não apresentaram mudanças significativas na sua eliminação.

É importante frisar que o catalisador de FCC possui a forma de um pó fino, entretanto, antes de qualquer ensaio ou análise o catalisador é homogeneizado para assegurar que represente o lote como um todo. Por intermédio dos valores obtidos por meio da técnica de EDX é possível considerar heterogeneidade no próprio lote. Vale lembrar que o catalisador contaminado nada 
mais é que um catalisador virgem que sofreu o processo de contaminação com níquel. Logo, ambos deveriam apresentar uma porcentagem elementar similar, sendo que as análises mostram resultados levemente diferentes, reforçando os indícios de heterogeneidade.

$\mathrm{Na}$ TAB. 6 é apresentada a comparação do tratamento com diclorometano nos catalisadores contaminados; é possível verificar que tal processo não recebe contribuição significativa da irradiação por feixe de elétrons (20 kGy) no que diz respeito à eliminação de níquel (NiO). Tal processo só é intensificado quando o tempo de refluxo aumenta, no caso analisado, de 60 minutos para 220 minutos.

Utilizando-se da técnica de difração de raios $X(D R X)$ foi possível verificar se a radiação nas determinadas doses foi sufuciente para alterar a estrutura cristalina do catalisador, obtendo-se os difratogramas mostrados nas FIG. 15 e 16.

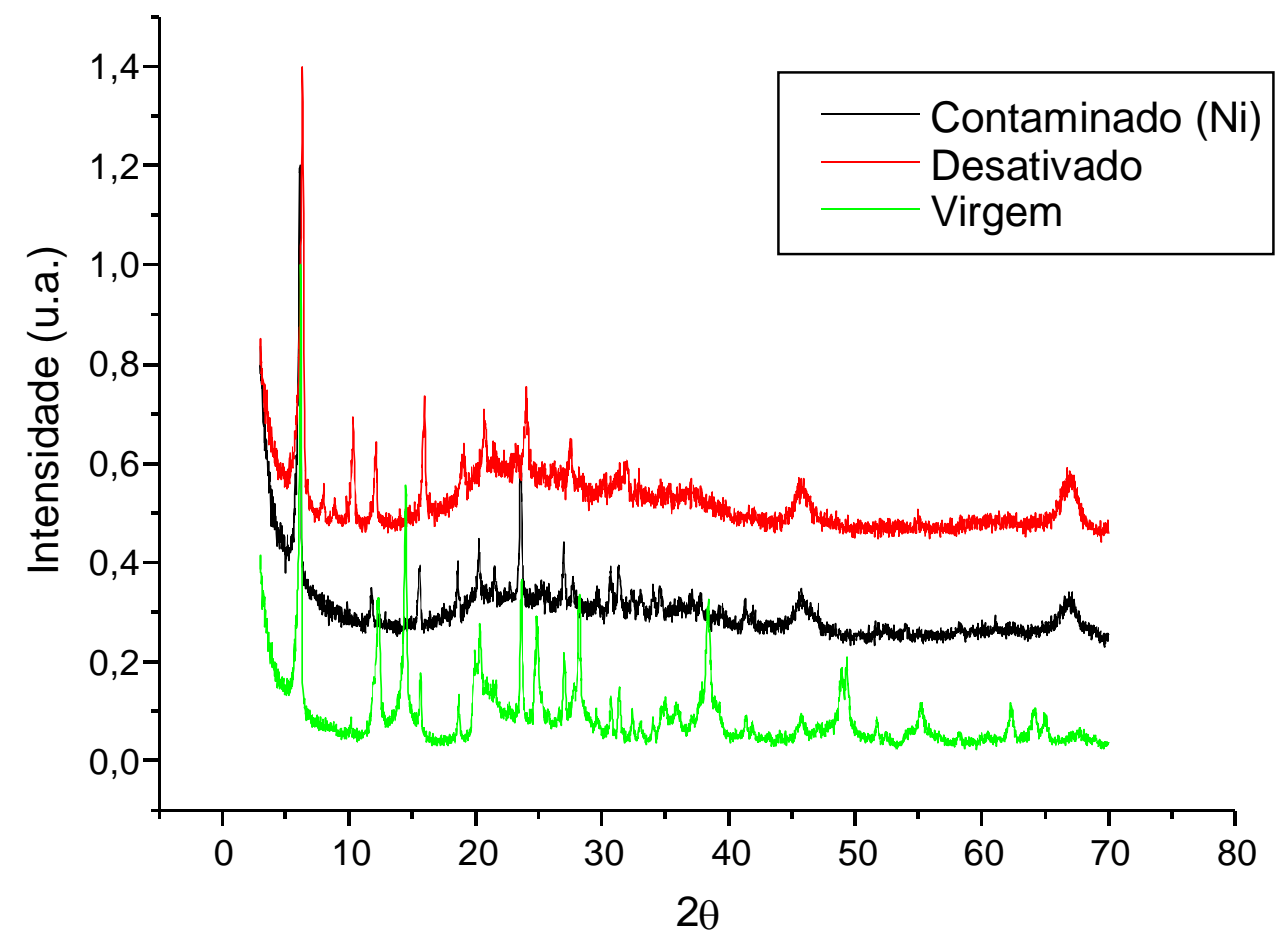

FIGURA 15 - Comparação dos difratogramas (DRX) dos catalisadores de FCC virgem, desativado e contaminado com níquel. 


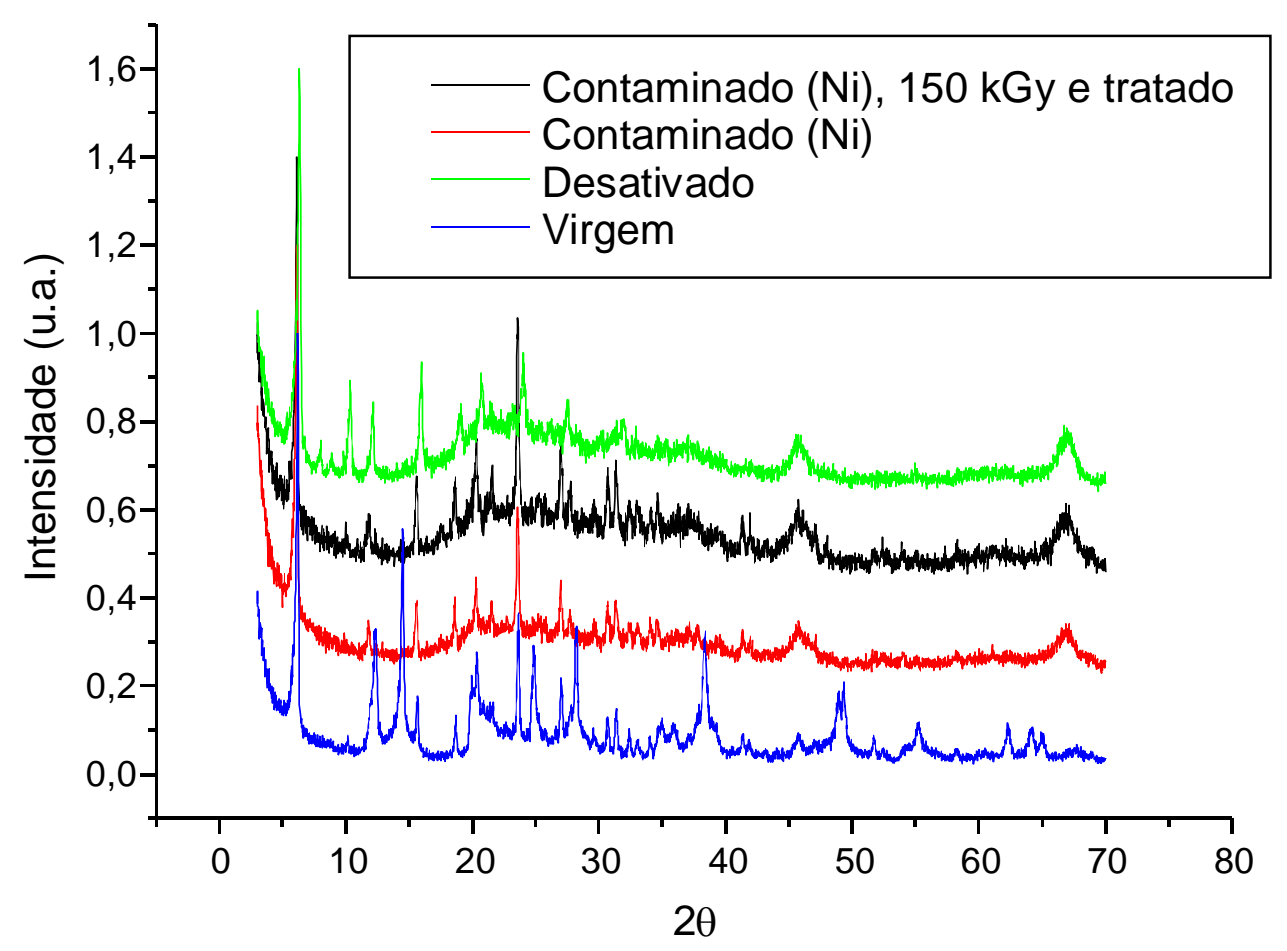

FIGURA 16 - Comparação dos difratogramas dos catalisadores de FCC virgem; contaminado com níquel; contaminado, irradiado a 150 kGy por feixe de elétrons e tratado com diclorometano; e desativado.

Inicialmente, observa-se que o processo de contaminação do catalisador virgem com níquel modifica cristalograficamente suas fases, ainda que não o torne similar ao desativado. Isso porque no processo de contaminação são aplicadas temperaturas elevadas no catalisador de FCC.

Contudo, é possível verificar que o catalisador contaminado com níquel encontra-se no estágio intermediário entre o virgem e o desativado do ponto de vista cristalográfico. As fases inicias de caolinita e boemita transformaram-se em uma fase amorfa e em alumina gama, respectivamente. Porém, a fase h-faujasita está presente e não como na fase de dióxio de silício como visto no desativado.

Já no tratamento para eliminação de níquel o catalisador contaminado, irradiado por feixe de elétrons com uma dose absorvida de 150 kGy e tratado com diclorometano, apresenta estrutura cristalina idêntica ao catalisador contaminado 
(FIG. 16). Assim, nem o tratamento com diclorometano nem o processamento por radiação, nessas condições, atuam diretamente na mudança de fases cristalinas do catalisador de FCC.

\subsubsection{Catalisador de HCC}

Na FIG. 17 é mostrado o diagrama esquemático da rota de trabalho utilizada para a abordagem do estudo do catalisador de HCC.

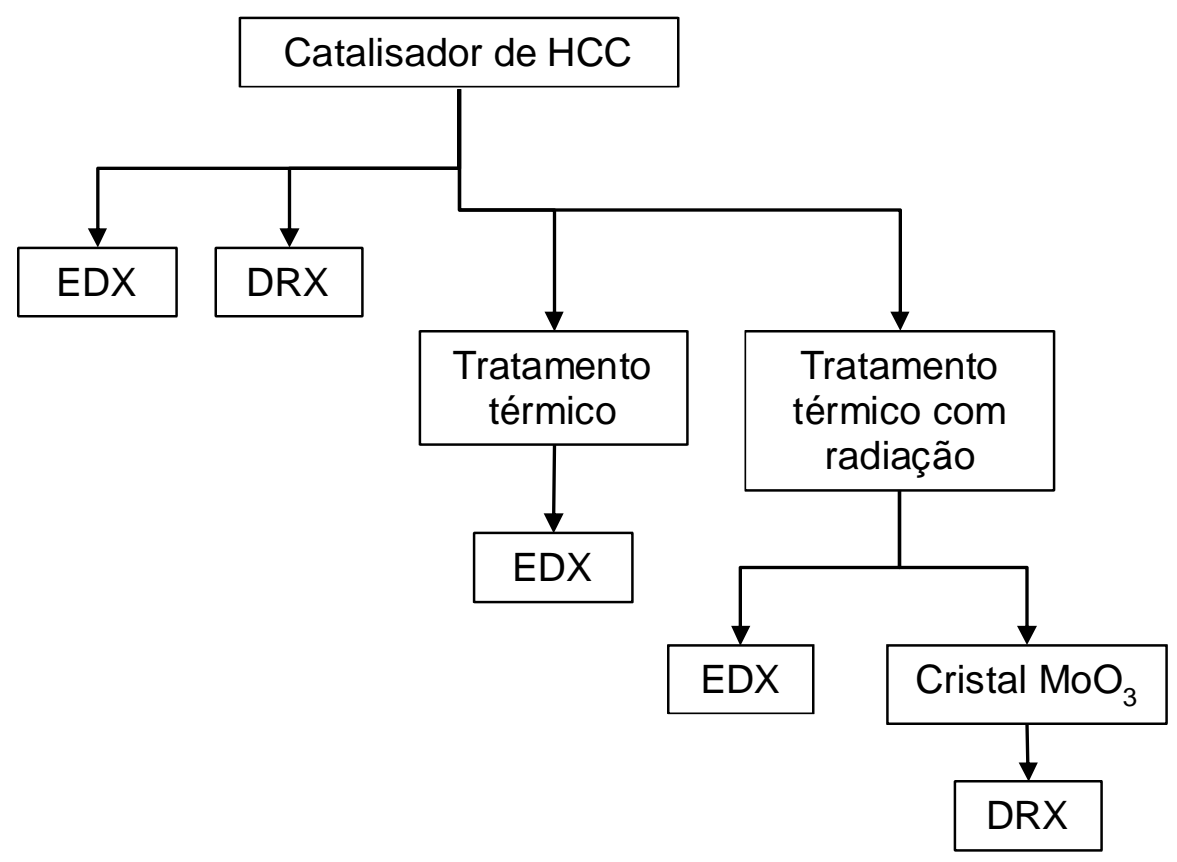

FIGURA 17 - Diagrama esquemático da rota de trabalho para o estudo do catalisador de HCC.

\subsubsection{Análises iniciais}

O catalisador de HCC é um extrudado de $4 \mathrm{~mm}$ a $8 \mathrm{~mm}$ de comprimento por $2 \mathrm{~mm}$ a $5 \mathrm{~mm}$ de diâmetro. Foram estudados os catalisadores de HCC de três etapas: virgem, desativado do leito inferior e o desativado do leito superior.

Esses catalisadores foram analisados por EDX para uma caracterização elementar inicial, conforme apresentado na TAB. 2. Entretanto, em função da heterogeneidade encontrada no catalisador de FCC, fez-se necessária uma análise 
mais minuciosa dos catalisadores de HCC. Para tal, as análises de EDX foram realizadas no Centro de Ciências e Tecnologia de Materiais (CCTM) do IPEN-CNEN/SP, em triplicatas.

Para se ter uma idéia inicial da estrutura cristalina do catalisador de $H C C$, esse foi submetido a análise de difração de raios $X(D R X)$. Pela análise dos difratogramas mostradas na FIG. 18 é possível compreender que os catalisadores não possuem fases cristalinas bem definidas. Assim, numa interpretação mais profunda serão usados os resultados de EDX para se avaliar a influência da irradiação com feixe de elétrons no catalisador, tendo como objetivo a extração de molibdênio, de alto valor agregado, acompanhando-se nesse caso a variação das porcentagens dos elementos estudados.

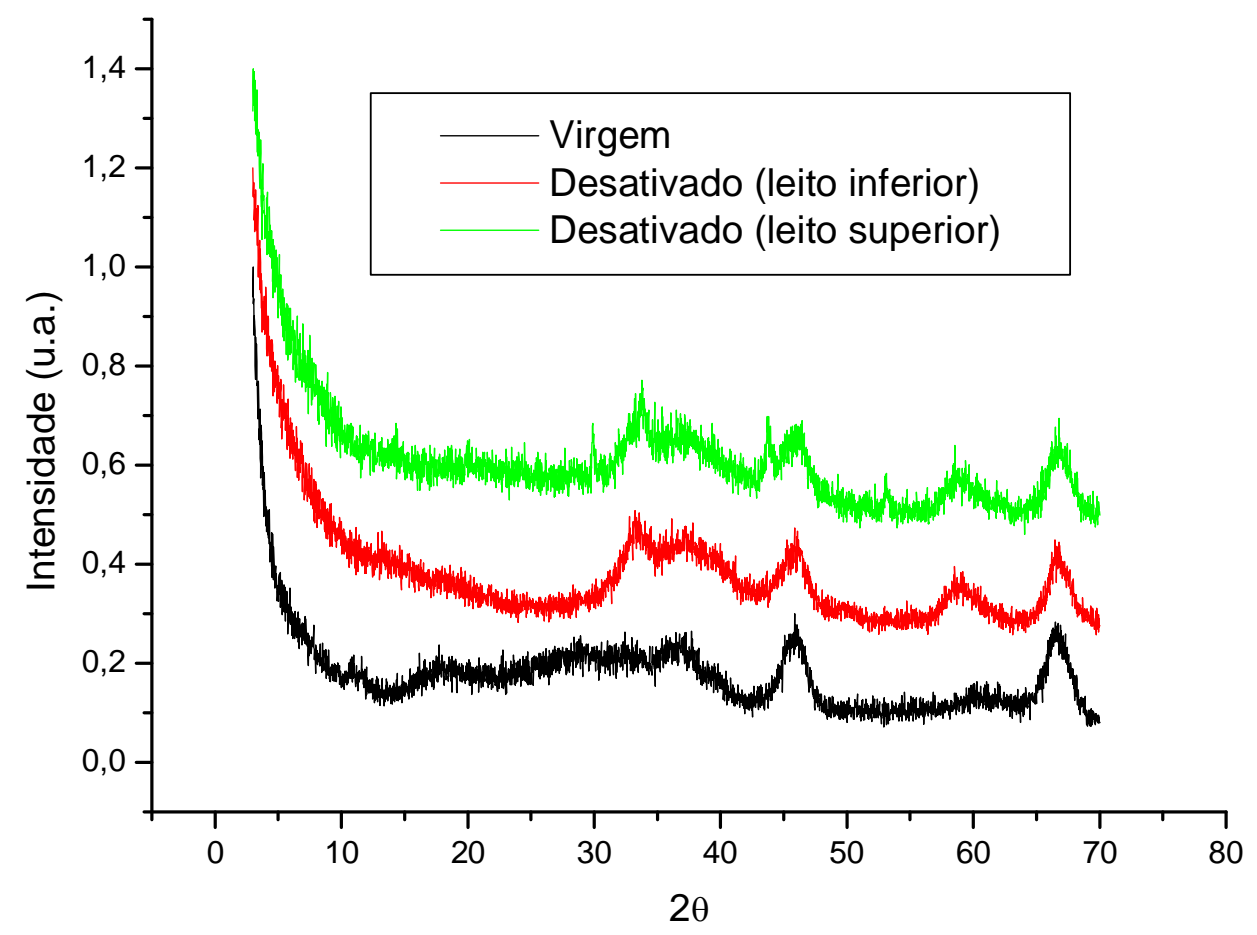

FIGURA 18 - Comparação dos difratogramas (DRX) dos catalisadores de HCC virgem e desativados do leito inferior e superior. 
Encontraram-se esferas cerâmicas durante o processo de moagem do catalisador desativado do leito superior, as quais eram difíceis de serem maceradas. Essas esferas foram lavadas com água e secas para não haver a influência de resíduo do catalisador em sua superfície. Após estarem limpas foram enviadas ao CCTM para serem submetidas à difração de raios $\mathrm{X}$ (DRX). Por meio do difratograma mostrado na FIG. 19, observa-se que essa esfera é constituída basicamente de alumina- $\alpha$, e provavelmente não foi formada no processo e sim adicionada para auxiliar na desaglutinação do coque no catalisador de HCC.

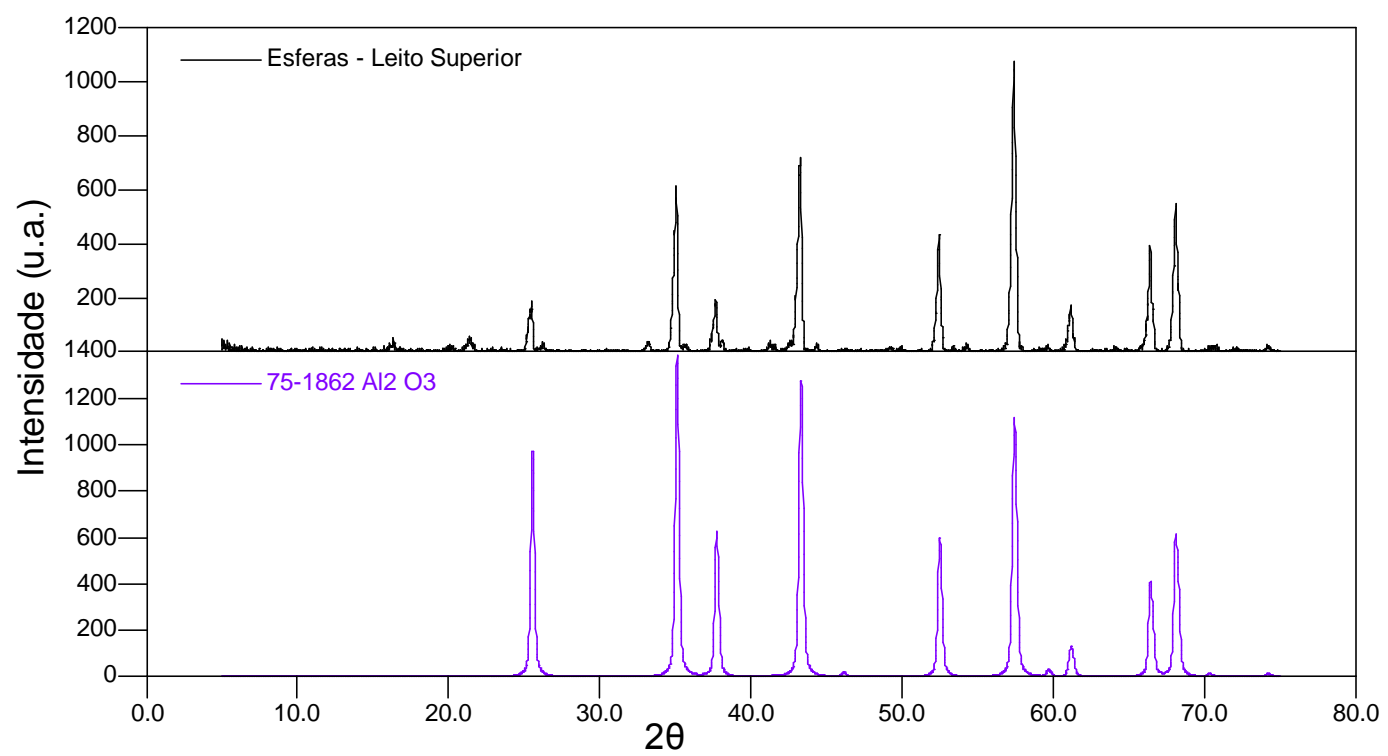

FIGURA 19 - Difratograma das esferas (alumina- $\alpha$ ) encontradas no catalisador de HCC do leito superior.

Os catalisadores desativados possuem em sua composição elementos químicos (molibdênio, níquel e cobalto) de valor agregado, que valem suas extrações. Portanto, métodos que facilitem a retirada desses elementos torna o processo exequível financeiramente.

Vale ressaltar que os catalisadores de HCC enquadram-se como resíduo perigoso. Portanto, com base nos estudos do Departamento de Química da Universidade Estadual de Moscou em parceria com o Instituto de Tecnologia de Belgorod (Lunin et al., 1993) fizeram-se os ensaios para extração de molibdênio. 


\subsubsection{Preparo das amostras}

Para que seja possível compreender se a irradiação com feixe de elétrons de média energia aliada a um tramento térmico, colabora na extração de molibdênio do catalisador faz-se necessária uma comparação com o método térmico.

Portanto, para se obter a informação desejada os catalisadores de HCC foram preparados em duas rotas distintas, detelhadas nos itens: tratamento térmico e tratamento térmico com radiação.

Tratamento térmico - No ensaio de tratamento térmico ou thermal treatment (TT) o catalisador de HCC foi disposto dentro de um cadinho de alumina, posicionado sobre o dispositivo de aquecimento montado no Centro de Tecnologia das Radições (CTR), com a resistência de um acessório para aquecimento em altas temperaturas do difratômetro de raios X Multi-Flex. A resistência foi conectada a um transformador de tensão variável e ligado a corrente alternada. Para assegurar que nenhuma sobrecarga fosse depositada à resistência, acoplou-se uma lâmpada de filamento de tungstênio que servia como fusível ao sistema, além de alertar a passagem de corrente elétrica.

O sistema foi dotado de três multímetros, um para o controle de temperatura efetuado pelo termopar tipo $\mathrm{R}$ (filamento de Pt-Rh 13\%, com 0,2 mm de diâmetro) sendo que sua leitura em milivolts foi convertida em graus Celcius utilizando-se a tabela de conversão; um segundo multímetro calibrado, para comparação de temperatura, efetuado por um termopar do tipo K (filamento de cromel-alumel), obtendo o valor diretamente em graus Celcius; e um último para acompanhar a voltagem aplicada ao sistema de aquecimento.

Na FIG. 20 é mostrado o sistema de aquecimento montado para ensaios de temperatura, sem a colaboração proveniente da irradiação com feixe de elétrons.

Nesses ensaios utilizaram-se apenas os catalisadores de HCC desativados, considerados como resíduo sólido do processo de refino de petróleo. 


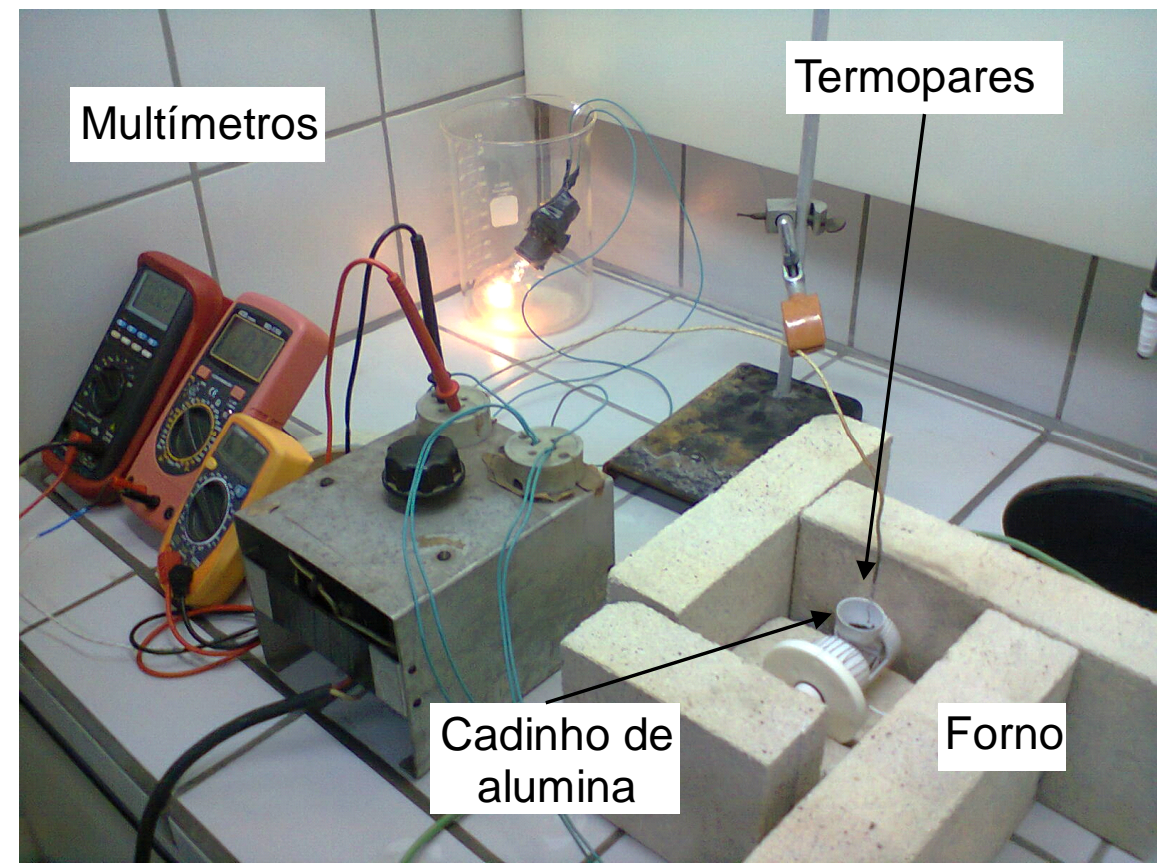

FIGURA 20 - Sistema de aquecimento do catalisador de HCC com controle de temperatura.

Foram realizados quatro ensaios, dois deles com o catalisador desativado de HCC do leito inferior e os outros dois com o catalisador desativado do leito superior.

Os catalisadores de HCC desativados do leito inferior foram tratados termicamente nas temperaturas médias de trabalho de $747^{\circ} \mathrm{C}(\mathrm{TT}-1)$ e $650^{\circ} \mathrm{C}$ (TT-2). Já os catalisadores de HCC desativados do leito superior foram tratados termicamente nas temperaturas médias de $916{ }^{\circ} \mathrm{C}$ (TT-3) e $1056{ }^{\circ} \mathrm{C}(\mathrm{TT}-4)$. Ambos os catalisadores foram tratados no mesmo sistema de aquecimento mostrado na FIG. 20, por um período de 20 minutos.

Após o tratamento térmico o catalisador foi recolhido e resfriado em dessecador, macerado e enviado para análises de EDX. Confrontando-se os dados de EDX antes e após o tratamento térmico, fez-se o estudo da porcentagem de molibdênio extraído. 
Tratamento térmico com radiação - Esse ensaio diz respeito ao tratamento térmico juntamente com a irradiação por feixes de elétrons de média energia, pois isso chamado de radiation-thermal treatment (RTT).

No que diz respeito a aplicação da radiação, os catalisadores foram irradiados, utilizando-se um acelerador industrial de elétrons, Dynamitron DC 1500/25/04, modelo JOB 188, utilizando-se os padrões de máquina com base nos estudos do Departament of Petroleum Chemistry and Organic Catalysis, Belgorod Technological Institute of Building Materials, and I.A. Grishmanova (Adigamov et al., 1988), energia de 1,3 MeV, uma corrente de 3,5 mA, em uma taxa de dose de 25,3 kGy/s, sendo que o porta-amostra ficou exposto ao feixe de elétrons por 20 minutos somando uma dose absorvida final no catalisador de HCC de 30,36 MGy.

Para que as amostras de catalisadores de HCC pudessem ser irradiadas, o sistema de aquecimento foi posicionado diretamente abaixo do feixe de elétrons, conforme mostrado na FIG. 21.

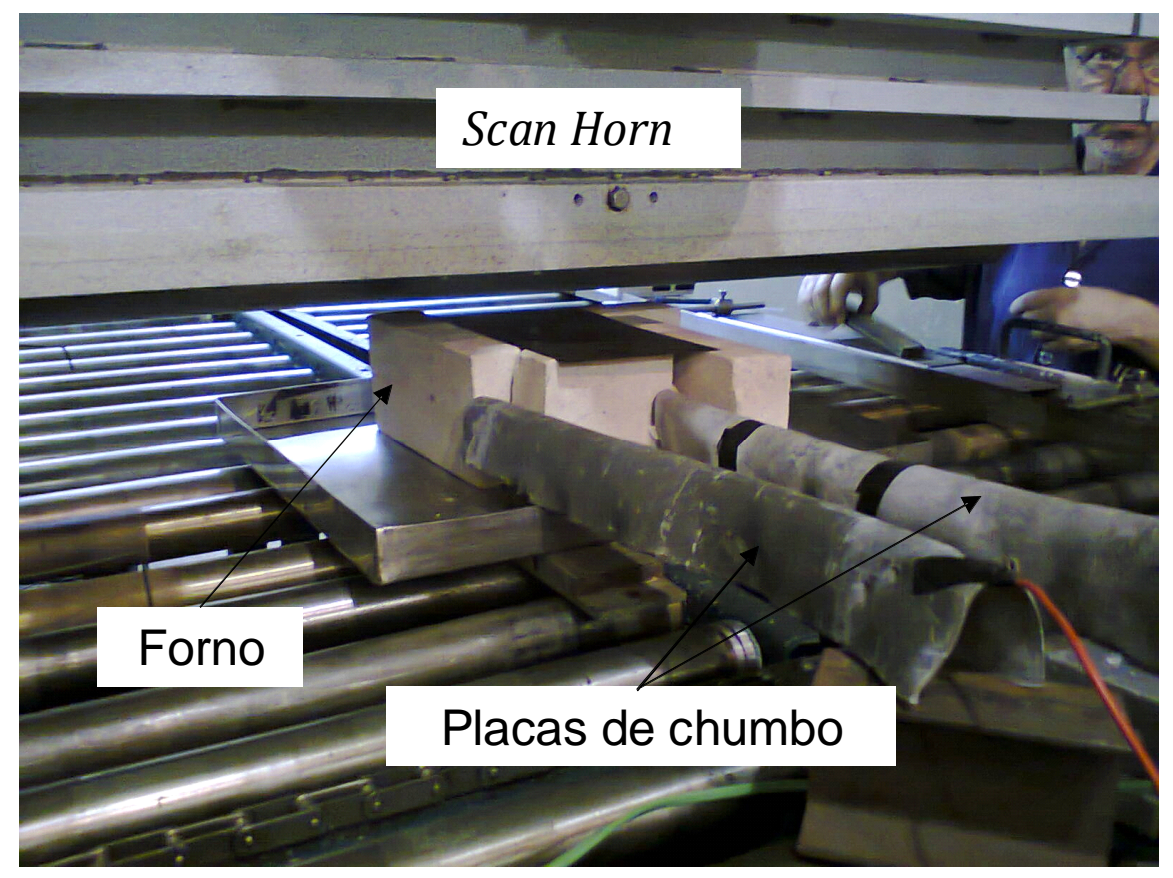

FIGURA 21 - Sistema de aquecimento do catalisador de HCC e irradiação simultânea com feixe de elétrons de 1,3 MeV, no IPEN-CNEN/SP. 
Para que o fluxo de ar que resfria o scan horn do acelerador não interferisse no aquecimento, assim como na perda do catalisador de HCC, a abertura superior do sistema de aquecimento foi recoberta com uma fina folha de titânio de $40 \mu \mathrm{m}$ de expessura. Trata-se do mesmo material utilizado na janela do scan horn, que mantém a região interna do acelerador de elétrons em vácuo e minimiza a atenuação do feixe de elétrons.

Os cabos elétricos e o cabo de compensação do termopar tipo R também foram recobertos com uma placa de chumbo, para que não houvesse nenhuma interação da radiação com o material polimérico dos cabos (FIG. 21).

O sistema de aquecimento foi o mesmo usado no tratamento térmico, com poucas alterações. Primeiramente, o sistema foi colocado sobre uma bandeja de aço inoxidável AISI304 para que pudesse ser manipulado com maior facilidade. Não foram usadas a lâmpada e o termopar tipo $\mathrm{K}$ de acompanhamento nesses ensaios. Foram utilizados dois multímetros, um para estabelecer a voltagem aplicada no sistema de aquecimento e outro para acompanhar a temperatura $\left({ }^{\circ} \mathrm{C}\right)$ por intermédio das leituras feitas pelo termopar tipo $\mathrm{R}$.

Após estabelecida a voltagem no sistema, o multímetro foi retirado da instalação. A temperatura do sistema foi acompanhada em tempo-real pelo lado externo da sala de irradiação do acelerador industrial de elétrons, Dynamitron DC1500/25/04, modelo JOB 188.

Assim como no tratamento térmico, foram realizados quatro ensaios de RTT, dois com o catalisador de HCC desativado do leito inferior e dois com o catalisador desativado do leito superior.

Os catalisadores de HCC desativados do leito inferior foram submetidos ao RTT nas temperaturas médias de ensaio de $765^{\circ} \mathrm{C}$ (RTT-1) e $540{ }^{\circ} \mathrm{C}$ (RTT-2). Os catalisadores desativados do leito superior foram tratados nas temperaturas médias de $908^{\circ} \mathrm{C}(\mathrm{RTT}-3)$ e $1058^{\circ} \mathrm{C}(\mathrm{RTT}-4)$.

Após o ensaio o catalisador foi recolhido e resfriado em dessecador, macerado e enviado para análises de EDX, no CCTM, do IPEN-CNEN/SP. 
Em ambos tratamentos (TT e RTT), os valores de temperatura foram obtidos pelo termopar tipo R. Entretanto, esse termopar encontra-se muito mais perto da resistência do que da amostra de catalisador de HCC.

Para a obtenção de valores de temperatura mais precisos, construiu-se uma curva de calibração utilizando o termopar tipo K calibrado como padrão. Este foi posicionado dentro do cadinho e feito o aquecimento progressivo, acompanhado pela leitura do termopar tipo R. Assim, obtiveram-se os dados de ambos os termopares. A curva de calibração é mostrada na FIG. 22.

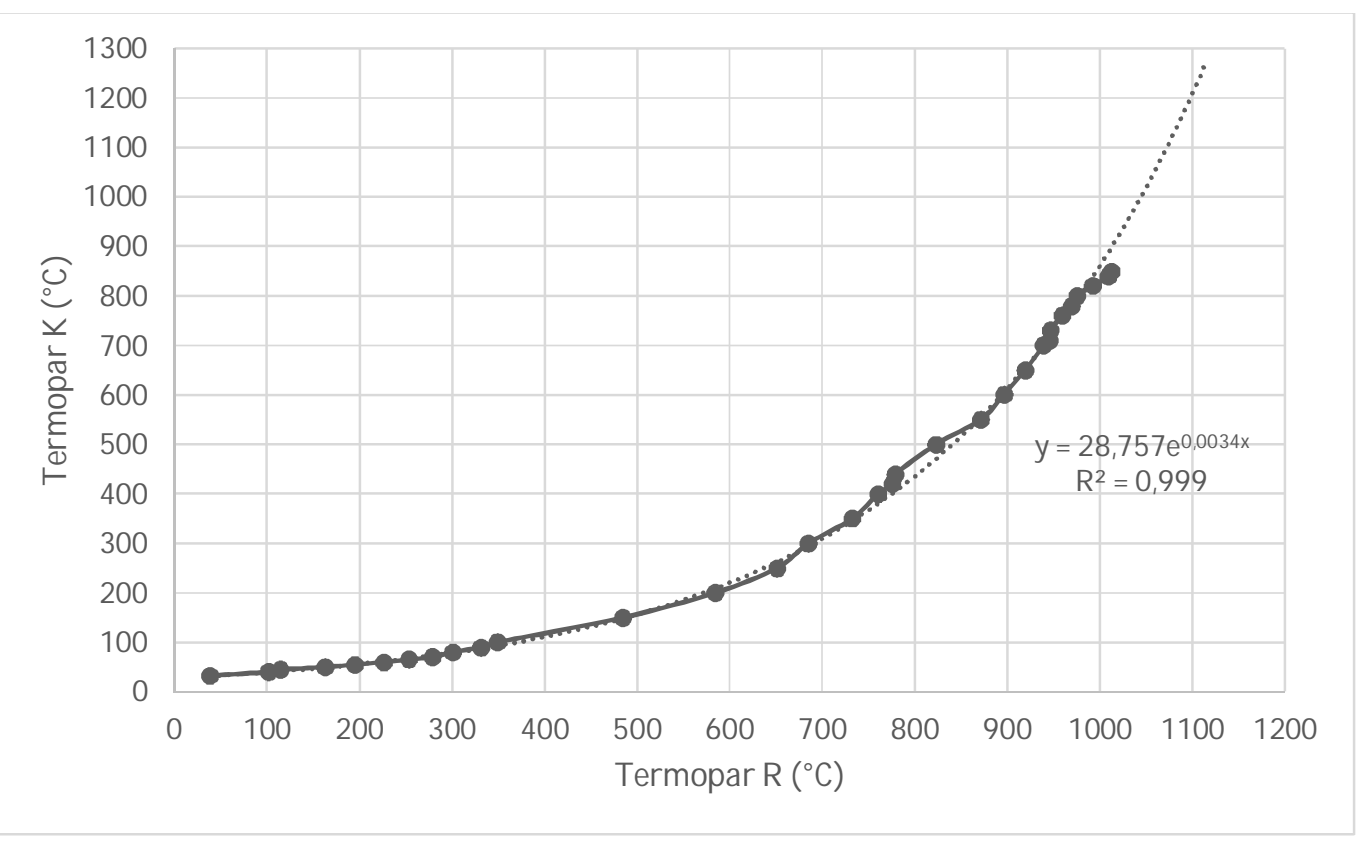

FIGURA 22 - Curva de calibração para medição de temperatura.

Tendo obtido a equação da reta que melhor representa o perfil da curva gerada pelos pontos de temperatura, aplicou-se essa equação aos valores obtidos pelo termopar tipo R, para a obtenção dos valores de temperatura corrigidos.

\subsubsection{Resultados e discussão}

Tratamento térmico - Após realizado o ensaio de temperatura nos catalisadores de HCC seguiu-se pela análise de EDX para estudar o rendimento da 
extração do molibdênio. Os resultados da composição química são apresentados na TAB. 7.

TABELA 7 - EDX dos catalisadores de HCC desativados do leito inferior e superior tratados termicamente.

\begin{tabular}{|c|c|c|c|c|}
\hline \multirow{2}{*}{$\begin{array}{c}\text { Óxidos } \\
(\%)\end{array}$} & \multicolumn{2}{|c|}{ HCC desativado (leito inferior) } & \multicolumn{2}{|c|}{ HCC desativado (leito superior) } \\
\hline & $\begin{array}{c}\mathrm{TT}-1 \\
\left(747^{\circ} \mathrm{C}\right)\end{array}$ & $\begin{array}{c}\text { TT-2 } \\
\left(650^{\circ} \mathrm{C}\right)\end{array}$ & $\begin{array}{c}\text { TT-3 } \\
\left(916^{\circ} \mathrm{C}\right)\end{array}$ & $\begin{array}{c}\text { TT-4 } \\
\left(1056^{\circ} \mathrm{C}\right)\end{array}$ \\
\hline $\mathrm{Al}_{2} \mathrm{O}_{3}$ & $56,274 \pm 0,107$ & $60,421 \pm 0,111$ & $48,324 \pm 0,112$ & $50,133 \pm 0,114$ \\
\hline $\mathrm{As}_{2} \mathrm{O}_{3}$ & $0,007 \pm 0,004$ & $0,015 \pm 0,005$ & $0,812 \pm 0,009$ & $0,753 \pm 0,009$ \\
\hline $\mathrm{CaO}$ & $0,126 \pm 0,003$ & $0,134 \pm 0,003$ & $0,145 \pm 0,003$ & $0,149 \pm 0,003$ \\
\hline $\mathrm{CO}_{2} \mathrm{O}_{3}$ & $0,009 \pm 0,003$ & $0,022 \pm 0,003$ & $0,020 \pm 0,004$ & $0,017 \pm 0,004$ \\
\hline $\mathrm{Fe}_{2} \mathrm{O}_{3}$ & $0,192 \pm 0,004$ & $0,191 \pm 0,004$ & $1,325 \pm 0,009$ & $1,279 \pm 0,009$ \\
\hline $\mathrm{MoO}_{3}$ & $17,926 \pm 0,016$ & $19,952 \pm 0,018$ & $18,292 \pm 0,017$ & $17,855 \pm 0,017$ \\
\hline $\mathrm{NiO}$ & $4,334 \pm 0,012$ & $4,955 \pm 0,014$ & $4,448 \pm 0,013$ & $4,590 \pm 0,013$ \\
\hline $\mathrm{P}_{2} \mathrm{O}_{5}$ & $4,404 \pm 0,022$ & $4,012 \pm 0,021$ & $3,049 \pm 0,023$ & $3,107 \pm 0,023$ \\
\hline $\mathrm{SeO}_{2}$ & - & - & $0,003 \pm 0,001$ & $0,002 \pm 0,001$ \\
\hline $\mathrm{SiO}_{2}$ & $0,025 \pm 0,019$ & - & $7,256 \pm 0,036$ & $6,713 \pm 0,036$ \\
\hline $\mathrm{SO}_{3}$ & $16,692 \pm 0,025$ & $10,271 \pm 0,021$ & $15,815 \pm 0,027$ & $14,924 \pm 0,027$ \\
\hline $\mathrm{V}_{2} \mathrm{O}_{5}$ & $0,008 \pm 0,007$ & $0,020 \pm 0,007$ & $0,495 \pm 0,012$ & $0,467 \pm 0,011$ \\
\hline $\mathrm{ZnO}$ & $0,004 \pm 0,001$ & $0,004 \pm 0,001$ & $0,016 \pm 0,001$ & $0,010 \pm 0,001$ \\
\hline
\end{tabular}

Para calcular o rendimento da extração de molibdênio faz-se necessário novamente o cálculo do balanço geral de massas. Nesse caso, escolheu-se o óxido de alumínio como elemento padrão $\left(\mathrm{Al}_{2} \mathrm{O}_{3}\right)$ em função do tratamento térmico não ser capaz de eliminá-lo, uma vez que seu ponto de ebulição encontra-se a $2980{ }^{\circ} \mathrm{C}$ (MSDS, Sigma-Aldrich), muito acima do utilizado no tratamento térmico.

Utilizando-se da Equação 2 é possível calcular a porcentagem de molibdênio $\left(\mathrm{MoO}_{3}\right)$ encontrado na amostra, e por consequência, o porcentual de sua extração efetuado pelo tratamento térmico.

Extração de molibdênio $(\%)=\frac{\left(\frac{M o O 3}{A l 2 O 3}\right) \text { depois }}{\left(\frac{M O O 3}{A l 2 O 3}\right) \text { antes }} x 100$ 
Com esses dados é possível assegurar uma extração de molibdênio $\left(\mathrm{MoO}_{3}\right)$ de $26,238 \% ; 23,537 \% ; 2,403 \%$ e $8,172 \%$ para os tratamentos TT-1; TT-2; TT-3; TT4, respectivamente.

Tratamento térmico com radiação - Após realizado o ensaio de temperatura e irradiação simultânea (RTT) nos catalisadores de HCC, seguiu-se pela análise de EDX para estudar o rendimento da extração do molibdênio $\left(\mathrm{MoO}_{3}\right)$. Os resultados da composição química são mostrados na TAB. 8.

TABELA 8 - EDX dos catalisadores de HCC desativados do leito inferior e superior tratados termicamente aliada a irradiação com feixe de elétrons (EB) e dose de 30,36 MGy.

\begin{tabular}{|c|c|c|c|c|}
\hline \multirow{2}{*}{$\begin{array}{l}\text { Óxidos } \\
(\%)\end{array}$} & \multicolumn{2}{|c|}{$\begin{array}{l}\text { HCC desativado (leito inferior) e } \\
\text { irradiado (EB) }\end{array}$} & \multicolumn{2}{|c|}{$\begin{array}{l}\text { HCC desativado (leito superior) e } \\
\text { irradiado (EB) }\end{array}$} \\
\hline & $\begin{array}{c}\text { RTT-1 } \\
\left(765^{\circ} \mathrm{C}\right)\end{array}$ & $\begin{array}{l}\text { RTT-2 } \\
\left(540^{\circ} \mathrm{C}\right)\end{array}$ & $\begin{array}{l}\text { RTT-3 } \\
\left(908^{\circ} \mathrm{C}\right)\end{array}$ & $\begin{array}{c}\text { RTT-4 } \\
\left(1058^{\circ} \mathrm{C}\right)\end{array}$ \\
\hline $\mathrm{Al}_{2} \mathrm{O}_{3}$ & $70,951 \pm 0,116$ & $59,589 \pm 0,113$ & $51,544 \pm 0,112$ & $52,960 \pm 0,114$ \\
\hline $\mathrm{As}_{2} \mathrm{O}_{3}$ & $0,007 \pm 0,003$ & $0,023 \pm 0,005$ & $0,760 \pm 0,009$ & $0,630 \pm 0,008$ \\
\hline $\mathrm{CaO}$ & $0,136 \pm 0,003$ & $0,130 \pm 0,003$ & $0,135 \pm 0,003$ & $0,106 \pm 0,003$ \\
\hline $\mathrm{Co}_{2} \mathrm{O}_{3}$ & $0,015 \pm 0,003$ & $0,019 \pm 0,003$ & $0,021 \pm 0,004$ & $0,016 \pm 0,003$ \\
\hline $\mathrm{Fe}_{2} \mathrm{O}_{3}$ & $0,213 \pm 0,004$ & $0,200 \pm 0,004$ & $1,212 \pm 0,009$ & $0,882 \pm 0,008$ \\
\hline $\mathrm{MoO}_{3}$ & $12,979 \pm 0,012$ & $19,840 \pm 0,018$ & $18,922 \pm 0,018$ & $18,907 \pm 0,018$ \\
\hline $\mathrm{NiO}$ & $5,354 \pm 0,012$ & $4,935 \pm 0,013$ & $4,621 \pm 0,013$ & $4,634 \pm 0,013$ \\
\hline $\mathrm{P}_{2} \mathrm{O}_{5}$ & $4,223 \pm 0,021$ & $4,281 \pm 0,022$ & $3,008 \pm 0,022$ & $3,081 \pm 0,022$ \\
\hline $\mathrm{SeO}_{2}$ & - & - & $0,001 \pm 0,001$ & $0,003 \pm 0,001$ \\
\hline $\mathrm{SiO}_{2}$ & $0,055 \pm 0,018$ & $0,004 \pm 0,016$ & $6,423 \pm 0,034$ & $4,880 \pm 0,031$ \\
\hline $\mathrm{SO}_{3}$ & $6,043 \pm 0,016$ & $10,969 \pm 0,022$ & $12,902 \pm 0,024$ & $13,536 \pm 0,025$ \\
\hline $\mathrm{V}_{2} \mathrm{O}_{5}$ & $0,020 \pm 0,006$ & $0,008 \pm 0,007$ & $0,437 \pm 0,011$ & $0,361 \pm 0,010$ \\
\hline $\mathrm{ZnO}$ & $0,004 \pm 0,001$ & $0,003 \pm 0,001$ & $0,013 \pm 0,001$ & $0,005 \pm 0,001$ \\
\hline
\end{tabular}

Para se compreender os dados obtidos pelo EDX no tratamento térmico aliado a irradiação por feixe de elétrons (RTT), realizaram-se os mesmos cálculos empregados no tratamento térmico (TT), utilizando-se a Equação 2. 
Vale ressaltar que os ensaios com feixe de elétrons elevam a temperatura até $558{ }^{\circ} \mathrm{C}$, decorrente da ação do bombardeio dos elétrons com energia de 1,3 MeV diretamente na amostra. Portanto, a temperatura máxima obtida é controlada pelo sistema de aquecimento. No caso do RTT a temperatura máxima obtida foi de $1058^{\circ} \mathrm{C}$ e a Equação 2 foi utilizada no cálculo de extração de molibdênio.

Obtendo-se, portanto, 57,642\%; 22,904\%; 5,348\% e 7,952\% de extração de molibdênio $\left(\mathrm{MoO}_{3}\right)$ para os tratamentos RTT-1; RTT-2; RTT-3 e RTT-4, respectivamente.

Na TAB. 9 são apresentados os resultados dos tratamentos TT e RTT, para maior facilidade na visualização.

TABELA 9 - Valores comparativos para os tratamentos TT e RTT aplicados aos catalisadores de HCC desativados do leito inferior e superior.

\begin{tabular}{c|c|c|c|c|c|c}
\hline \multicolumn{2}{c|}{ Tratamento térmico } & $\begin{array}{c}\text { Extração de } \\
\text { molibdênio } \\
(\%)\end{array}$ & $\begin{array}{c}\text { Temperatura } \\
\left({ }^{\circ} \mathrm{C}\right)\end{array}$ & $\begin{array}{c}\text { Extração de } \\
\text { molibdênio } \\
(\%)\end{array}$ & $\begin{array}{c}\text { Tratamento } \\
\text { térmico aliada } \\
\text { a irradiação } \\
\text { por feixe de } \\
\text { elétrons }\end{array}$ \\
\hline $\begin{array}{c}\text { HCC } \\
\text { (leito inferior) }\end{array}$ & TT-1 & 26,238 & 747 & 765 & 57,642 & RTT-1 \\
\cline { 2 - 7 } & TT-2 & 23,537 & 650 & 540 & 22,904 & RTT-2 \\
\hline $\begin{array}{c}\text { HCC } \\
\text { (leito superior) }\end{array}$ & TT-3 & 2,403 & 916 & 908 & 5,348 & RTT-3 \\
\cline { 2 - 7 } & TT-4 & 8,172 & 1056 & 1058 & 7,952 & RTT-4 \\
\hline
\end{tabular}

Nos gráficos das FIG. 23 e 24 são comparados o tratamento térmico (TT) em relação ao tratamento térmico com radiação (RTT), para os catalisadores de HCC desativados do leito inferior e superior. 


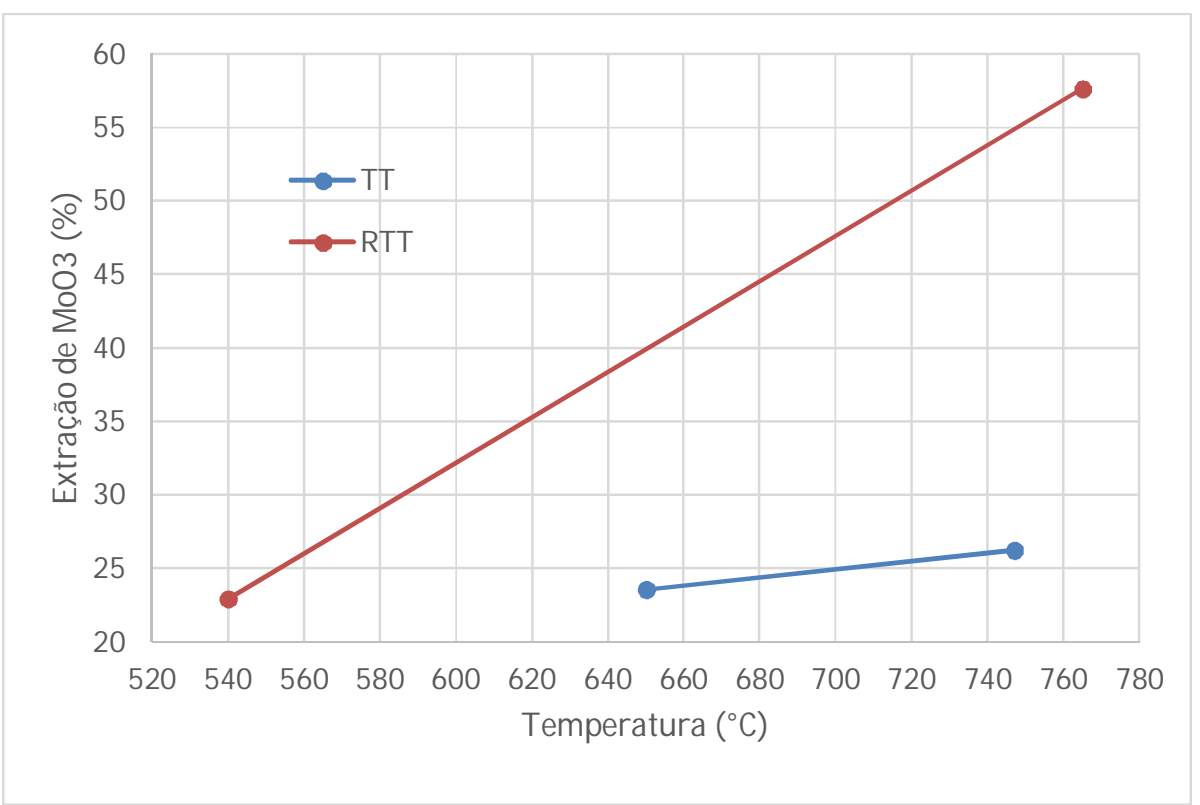

FIGURA 23 - Gráfico comparativo dos tratamentos TT e RTT nos catalisadores de HCC desativado do leito inferior.

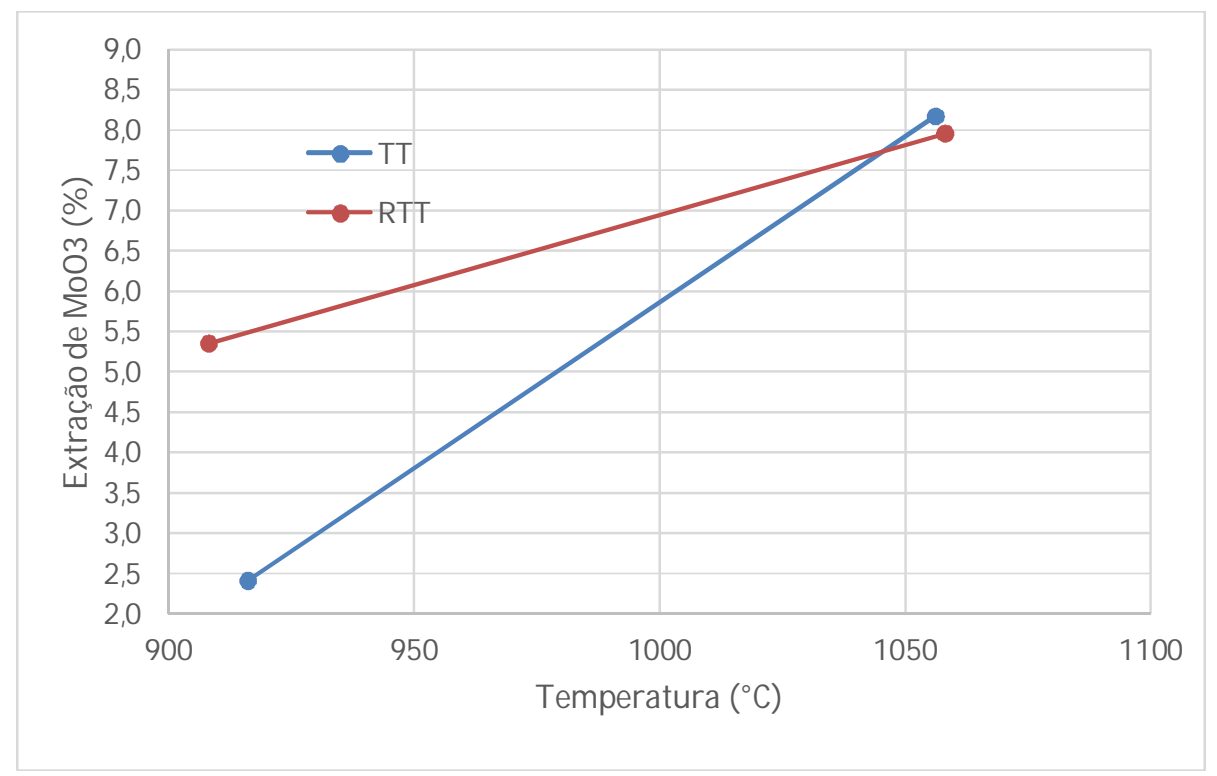

FIGURA 24 - Gráfico comparativo dos tratamentos TT e RTT nos catalisadores de HCC desativado do leito superior. 
É possível observar que a irradiação por feixe de elétrons favorece na extração de molibdênio $\left(\mathrm{MoO}_{3}\right)$ em ambos os casos. Contudo, nota-se maior contraste para os catalisadores desativados do leito inferior, sendo que quanto maior a energia térmica aplicada ao sistema, maior o rendimento da extração. Para os catalisadores desativados do leito superior, existe um maior rendimento na extração de molibdênio em temperaturas mais baixas $\left(900{ }^{\circ} \mathrm{C}\right)$; já em altas temperaturas $\left(1060^{\circ} \mathrm{C}\right)$ não é notada a contribuição da radiação.

Durante os tratamentos de radiation-thermal treatment foi observado no RTT-1 um cristal formado ao redor do cadinho de alumina, mostrado na FIG. 25. Após extração do cadinho e moagem analisou-se o cristal formado por DRX, cujo difratograma é mostrado na FIG. 26.
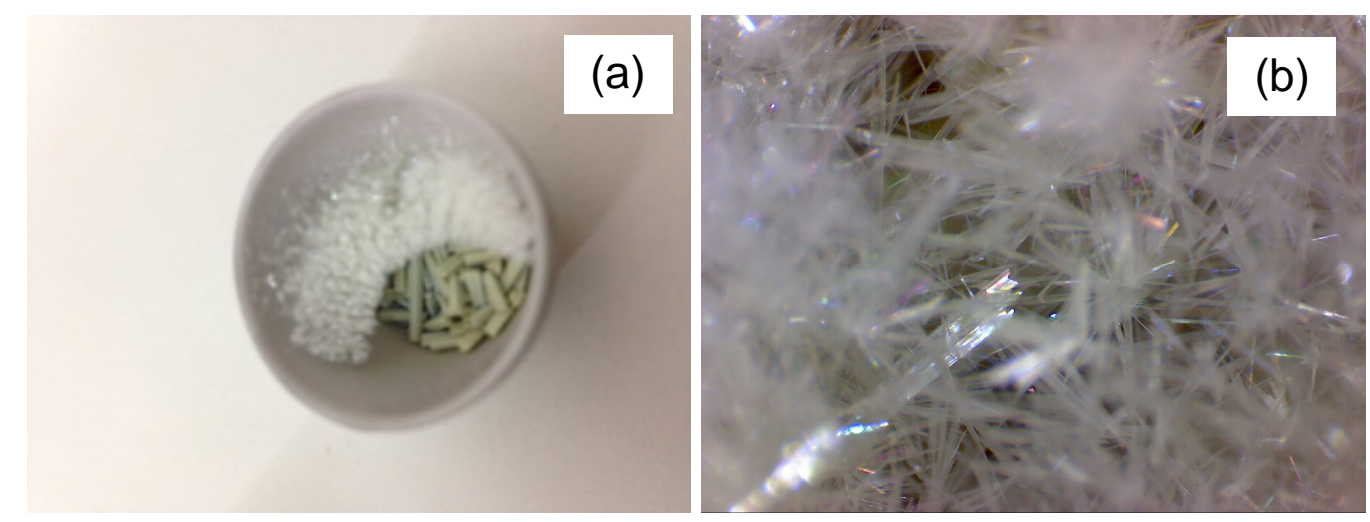

FIGURA 25 - Processamento do catalisador de HCC desativado (leito inferior) por RTT: a) cadinho de alumina e b) cristal formado após a irradiação por feixe de elétrons de 1,3 MeV. 


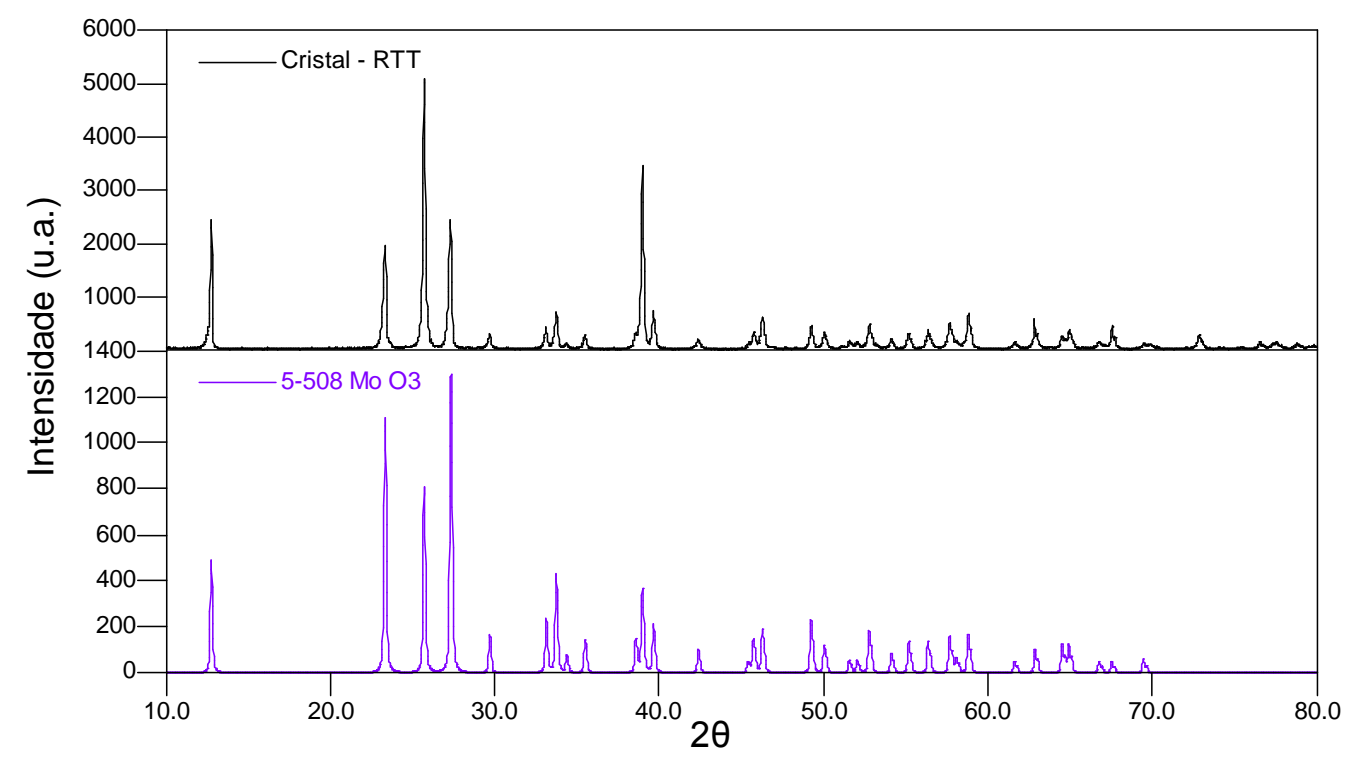

FIGURA 26 - Difratograma de Raios X (DRX) do cristal formado no processamento do catalisador de HCC desativado (leito inferior) por RTT.

Observa-se, portanto, que o cristal formado no tratamento por RTT-1 é o trióxido de molibdênio $\left(\mathrm{MoO}_{3}\right)$, extraído do catalisador de $\mathrm{HCC}$ desativado (leito inferior). É possível que as condições internas do forno favoreceram a recristalização do molibdênio. Já nos outros ensaios verificou-se a perda de molibdênio no catalisador processado por RTT e TT.

No processo de RTT a irradiação por feixe de elétrons de média energia reduz a temperatura de vaporização do trióxido de molibdênio $\left(\mathrm{MoO}_{3}\right)$ tornando possível sua sublimação com uma maior eficiência. Isso se deve a cristalização de algumas fases que contenham molibdênio, as quais são prontamente destruídas pela radiólise em altas temperaturas (Lunin et al., 1993).

A formação do cristal de molibdênio foi prevista por Solovetskii, o qual notou a deposição do cristal de $\mathrm{MoO}_{3}$ com $99,9 \%$ de pureza nas partes frias do aparato montado para o experimento de RTT (Solovestkii et al., 1998). 


\section{Capítulo 5}

\section{CONCLUSÃO}

Por intermédio dos dados obtidos no estudo voltado ao catalisador de FCC (Fluid Catalytic Cracking) é possível concluir que o processamento por radiação, seja feixe de elétrons de alta energia ou raios gama, nas condições estudadas, não colaboraram no processo de extração de lantânio $\left(\mathrm{La}_{2} \mathrm{O}_{3}\right)$, nem na eliminação do níquel, um dos contaminantes mais significativos para a desativação irreversível do catalisador.

A irradiação do catalisador desativado de HCC (Hidrocatalytic Cracking) do leito inferior com feixe de elétrons de 1,3 MeV de energia e dose absorvida de 30,36 MGy mostra-se eficiente no que diz respeito a extração de molibdênio $\left(\mathrm{MoO}_{3}\right)$, sendo que em temperaturas similares, em torno de $750{ }^{\circ} \mathrm{C}$, os catalisadores irradiados mostraram um rendimento aproximado de duas vezes maior em comparação ao não irradiado, ou seja, 57,65\% e 26,24\% respectivamente.

Para o catalisador desativado de HCC do leito superior a irradiação por feixe de elétrons também mostra-se eficiente na extração de molibdênio $\left(\mathrm{MoO}_{3}\right)$. Entretanto, de uma forma menos evidente, sendo que para temperaturas elevadas, em torno de $1050{ }^{\circ} \mathrm{C}$, a participação da radiação na extração é indiferente, ou seja, $7,95 \%$ e $8,17 \%$ para o catalisador desativado do leito superior irradiado e não irradiado, respectivamente. 


\section{Trabalhos futuros}

- Construir um dispositivo que seja possível recolher o molibdênio $\left(\mathrm{MoO}_{3}\right)$ que é extraído pelo processo RTT (radiation-thermal treatment) dos catalisadores de HCC (hidrocatalytic cracking) desativados dos leitos superior e inferior.

- Otimizar os parâmetros de temperatura versus doses absorvidas na recuperação de molibdênio $\left(\mathrm{MoO}_{3}\right)$ dos catalisadores de $\mathrm{HCC}$, processados por feixe de elétrons. 


\section{REFERÊNCIAS BIBLIOGRÁFICAS}

1. ABADIE, E. Processo de Refino. Material compilado pela Petrobrás, Curitiba, 2002.

2. ADIGAMOV, B.YA.; LUNIN, V.V.; MIROSHNICHENKO, I.I.; et at., Vestn. Mosk. Univ., Ser. 2: Khim., Vol. 29, p. 395, 1988.

3. ADZHIEV, A.YU., ADIGAMOV, B.YA., LUNIN, V.V., MIROSHNICHENKO, I.I., PANTELEEV, D.M., RYABCHENKO, P.V., SADOVNICHAYA, M.V., SOLOVETSKII, YU.I., TALESKII, YU.V. Radiation and Heat-Induced Phase Transitions in the Structure of Iron-Containing Catalysts for the Process of Direct Oxidation of Hydrogen Sulfide to Sulfur. Kinetic and Catalysis, Vol.32, 1991.

4. AFONSO, J.C., AGUIAR R.M., SILVA G.C. O Problema do descarte de catalisadores industriais de hidrotratamento. Bol. téc. Petrobras, Rio de Janeiro, 46 (3/4): 325 - 333, jul./dez., 2003.

5. AFONSO, J.C., LAJTER, K., GÓES, R.S. Recuperação de metais de catalisadores usados de hidrotratamento (NiMo e CoMo/ $\mathrm{Al}_{2} \mathrm{O}_{3}$ ). Química Nova, Vol.20, No.4, 1997.

6. AFONSO, J.C., SILVA, N., SALVATO, G.N., BUSNARDO, R.G. Recuperação de metais catalisadores de hidrorrefino usados via fusão com KHSO 4. Química Nova, Vol. 29, No.4, p.856-861, 2006.

7. ALDRICH - AL-228: Sugestões para limpeza de vidrarias. Disponível em: $<$ http://www.sigmaaldrich.com/etc/medialib/docs/Aldrich/Bulletin/al_techbull _al228.Par.0001.File.tmp/al_techbull_al228.pdf>. Acessado em 14 de Abril de 2014.

8. ALI, M. A., TATSUMI, T., MASUDA, T. Development of heavy oil hydrocracking catalysts using amorphous silicaalumina and zeolites as catalyst supports. Applied Catalysis A: General; Vol.233, p.77-90, 2002.

9. ARMOR, J.N. A History of Industrial Catalysis. Catalysis Today, Vol.163, 2011. 
10. BADER, N. Catalyst handling, disposal become more important in environmental era. Oil and Gas Journal, Tulsa, Vol.94, No.12, p.64-66, 1996.

11. BBC - Science, Rocks and minerals. Disponível em:

<http://www.bbc.co.uk/schools/gcsebitesize/science/add_ocr_pre_2011/che micals/rocksmineralsrev3.shtml>. Acessado em 10 de Junho de 2014.

12. BINNEMANS. K.; JONES, P.T.; BLANPAIN, B.; GERVEN, T.V.; YANG, Y.; WALTON, A.; BUCHERT, M. Recycling of rare earths: a critical review. Journal of Cleaner Production, p. 1-22, Vol. 51, 2013.

13. BURGESS, W.A. Identificação de possíveis riscos à saúde do trabalhador nos diversos processos industriais. 1. ed. Belo Horizonte: Ergo Editora, 1997.

14. BUSNARDO, R.G., Estudo da viabilidade técnica da recuperação de metais de catalisadores gastos de hidrotratamento via fusão com $\mathrm{KHSO}_{4}$. Dissertação (Mestrado em Química Analítica) Rio de Janeiro: UFRJ/IQ, 2005.

15. CABRAL, R.P.B., AZEVEDO JÚNIOR, A.F., CARVALHO, M.W.N.C., SANTOS, A.C.B., SILVA, M.A. Síntese dos suportes zeólita beta e SAPO-5 destinados a reação de HCC. $3^{\circ}$ Congresso Brasileiro de P\&D em Petróleo e Gás, 2005.

16. CERQUEIRA, H.S., CAEIRO, G., COSTA, L., RIBEIRO, F.R. Deactivation of FCC catalysts. Journal of Molecular Catalysis A: Chemical, Vol.292, p.113, 2008.

17. DECROOCQ, D. Catalytic cracking of heavy petroleum fractions. $1^{\frac{a}{a}} \mathrm{ed}$. Paris: Technip, 1984. p. 123.

18. DUARTE, C.L. Aplicação do processo avançado de oxidação por feixe de elétrons na degradação de compostos orgânicos presentes em efluentes industriais. Tese (Doutorado em Ciência na Area de Tecnologia Nuclear- Aplicações) - Instituto de Pesquisas Energéticas e Nucleares, Universidade de São Paulo, 1999.

19. ECODEBATE, publicado em 16 de Agosto de 2008. Disponível em: $<$ http://www.ecodebate.com.br/2008/08/16/impasse-sobre-reducao-deenxofre-no-diesel-esta-longe-do-fim-dizem-ongs/>. Acessado em 14 de Abril de 2014. 
20. ENGELHARD COPORATION. Millennium TM: Fluid catalytic Cracking Catalysts, [S.L.], 1994. Disponível em:

<http://www.refiningonline.com/EngelhardKB/prod/PBRMil.htm>. Acessado em 14 de Abril de 2014.

21. CETESB - Ficha de Informação Toxicológica. Disponível em: <http://www.cetesb.sp.gov.br/userfiles/file/laboratorios/fit/niquel.pdf> Acessado em 14 de Abril de 2014.

22. GUISNET, M., COSTA, L., RIBEIRO, F.R. Prevention of zeolite deactivation by coking. Journal of Molecular Catalysis A: Chemical, Vol. 305, p.69-83, 2009.

23. HE, H., MENG, J. Recycling rare earth from spent FCC catalyst using P507 (HEH/EHP) as extractant. Zhongnan Daxue Xuebao, Ziran Kexueban, Vol. 42, p. $2651-2657,2011$.

24. HUMMEL, A. The Chemistry of Alkanes and Cycloalkanes. Radiation Chemistry of Alkanes and Cycloalkanes, pp. 743-780, 1992.

25. IR-Spectra, Institute of Chemistry, University of Tartu, Estonia. Disponível em:

$<$ http://tera.chem.ut.ee//R_spectra/index.php?option=com_content\&view=ar ticle\&id=41\&ltemid=53>. Acessado em 12 de Junho de 2014 .

26. KERESZTURY, G., KISS, A. B., FARKAS, L. Raman and i.r. spectra and structure of boehmite (Y-AIOOH). Spectrochimica Acta, Vol. 36A, 1980.

27. LIMA, T.S., CAMPOS, P.C., AFONSO, J.C. Solubilização de catalisadores desativados em meio contendo fluoreto - II: Catalisadores de hidrotratamento. Ból. téc. PETROBRAS, Rio de Janeiro, 41 (3/4): 169-178, jul./dez. 1998.

28. LUNIN, V.V., MIROSHNICHENKO, I.I., PANTELEEV, D.M., SOLOVETSKII, YU.I. Extraction and Purification of Molybdenum from Deactivated Hydrodesulfurization Catalysts by Radiation-Thermal Treatment. Kinetic and Catalysis, Vol.34, 1993.

29. MINISTÉRIO DO MEIO AMBIENTE. Resolução № 315, de 29 de Outubro de 2002. Conselho Nacional Do Meio Ambiente - CONAMA.

30. MITCHELL, B. R. Metal Contamination of Cracking Catalysts. Ind. Eng. Chem. Res. Dev. (1980) 209-213. 
31. MSDS - Sigma-Aldrich. Disponível em:

$<$ http://www.sigmaaldrich.com/MSDS/MSDS/DisplayMSDSPage.do?country $=$ BR\&language $=$ pt\&productNumber $=319767 \&$ brand $=S I A L \& P a g e T o G o T o U$ $\mathrm{RL}=\mathrm{http} \% 3 \mathrm{~A} \% 2 \mathrm{~F} \% 2 \mathrm{Fwww}$. sigmaaldrich.com\%2Fcatalog\%2Fproduct $\% 2 \mathrm{Fsi}$ al\%2F319767\%3Flang\%3Dpt>. Acessado em 10 de Junho de 2014.

32. MYRSTAD, T.; SELJESTOKKEN, B.; ENGAN, H.; RYTTER, E. Effect of nickel and vanadium on sulphur reduction of FCC naphtha. Applied Catalysis A: General, p. 299-305, Vol.192, 2000.

33. NATIONAL ENERGY TECHNOLOGY LABORATORY. A Literature Review on Cold Cracking of Petroleum Crude Oil. Energy Policy Act of 2005 Section 1406, 2005.

34. National Institute of Standards and Technology (NIST): Chemistry, WebBook. Disponível em:

<http://webbook.nist.gov/cgi/cbook.cgi?ID=B6004665\&Mask=80\#IR-Spec>. Acessado em 12 de Junho de 2014.

35. OELDERIK, J.M., SIE, S.T., BODE, D. Progress in the Catalysis of the Upgrading of Petroleum Residue. Applied Catalysis, Vol.47, 1989.

36. PAPINI, C.J. Estudo comparativo de métodos de determinação do tamanho de partícula. Dissertação (Mestrado em Ciências na Área de Tecnologia Nuclear - Materiais) - Instituto de Pesquisas Energéticas e Nucleares, Universidade de São Paulo, 2003.

37. SALOMON, M. Folha de São Paulo, em Brasília, 04/09/2008. Disponível em: < http://www.nossasaopaulo.org.br/portal/node/1135>. Acessado em 14 de Abril de 2014.

38. SHREVE, R.N., Jr. BRINK, J. A. Indústria de Processos Químicos. 4. ed. Rio de Janeiro: Guanabara, 1977.

39. SOLOVETSKII, YU.I., PANTELEEV, D.M., LUNIN, V.V. High-Temperature Electron Irradiation and Radiation-Thermal Technology for Utilization, Purification and Production of Some Metals. Radiation Physics Chemistry, Vol.52, 1998.

40. UPSON, L. L. What FCC catalyst test show. Hydroc. Proc., nov., p. 253258, 1981.

41. VIERHEILIG, A.A. Methods of Recovering Rare Earth Elements. US Patent No.8,263,028; 2012.

42. WILSON, J. W. Fluid Catalytic Cracking: Technology and Operation. Tulsa: Pennwell Books, 1997. p. 323. 
43. WOJCIECHOWSKI, B. W; CORMA, A. Catalytic Cracking: Catalyst, Chemistry, and Kinetics. Chem. Ind. Ser., n. 25. New York: Marcel Dekker, Inc., 1986. p. 235.

44. WOJNÁROVITS, I. Radiaton Chemistry. Handbook of Nuclear Chemistry Chemical applications of nuclear reactions and radiations, 2003.

45. YOUSSEF, A.M.; EL KHERBAWY, M. A. SAMRA, S.E. Effect of irradiation with gamma-rays on the surface and catalytic properties of SiO2-Al2O3 and Li2O-ompregnated SiO2-Al2O3 systems. Radiat. Phys. Chem, p. 559 - 563, Vol. 40, 1992.

46. YOUSSEF, A.M.; EL-NABARAWY, TH.; MOSTAFA, M.R. Modification of surface properties of silica-alumina by irradiation with gamma-rays. Radiat. Phys. Chem, p. 439 - 443, Vol. 36, 1990.

47. YU, Z.S., CHEN, M.B. Rare Earth Elements and Their Applications. Metallurgical Industry Press, Beijing (P.R. China), 1995.

48. ZENZ, F. A. Help from Project E-A-R-L. Hydrocarbon Processing, p. 119, Abril 1974. 